\title{
The Direct Effect of Corporate Law on Entrepreneurship
}

\author{
Jorge Guzman
}

Columbia University and NBER*

\begin{abstract}
From 1946 to 1983 , U.S. states modernized their corporate law by adopting the Model Business Corporation Act (MBCA), a compendium of legal best practices. Better corporate law increased entrepreneurship. After the adoption of the MBCA, the number of new local corporations increased by $26 \%$ on average, half of which was substitution from other firm types, and the rest was net-new firms. States that only partially adopted saw no benefit, and the largest increases were concentrated in regions with ex-ante lower quality law. At the individual level, people in states adopting the MBCA also report higher self-employment levels, but no higher wage employment or labor force participation. Consistent with the MBCA increasing efficiency and decreasing regulatory capture, the effect was larger for women, black, and those located outside the central city.
\end{abstract}

\section{Introduction}

Finance depends on good corporate law (La Porta et al., 1998; Landes et al., 2012). This is particularly true for risky investments such as entrepreneurship (Lerner and Schoar, 2005; Djankov et al., 2002). By providing clear rules governing the behavior of firms and their managers, good corporate law reduces transaction costs and alleviates principal-agent problems (Williamson, 1975;

*I am thankful to Tania Babina, Seth Carnahan, Dan Gross, Simon Freyaldenhoven, Ryan McDevitt, Will Mullins, Casimiro Nigro, Jean Oh, Roberta Romano, Caitlin Slattery, Scott Stern, Lori Yue, and Giorgio Zanarone for helpful comments. I also thank participants at the Law and Finance Seminar in Geothe University. Finally, the editor Rafaella Sadun and two very helpful reviewers. Yupeng Liu provided excellent research assistantship in this project. This project is supported by the Kauffman Foundation. Email: jag2367@columbia.edu. All errors and omissions are my own. 
Romano, 1993; Cooter and Schäfer, 2011). This paper asks whether corporate law improvements can ultimately increase regional entrepreneurship, considering the case of the United States.

The United States has a distinct approach to corporate law, anchored around its federalist tradition (Romano, 1985, 1993). Rather than corporate law being centralized at the national level, states choose and introduce their corporate law charters virtually independently. Firms are allowed to choose any state as their state of incorporation - a sort of statutory domicile-independent of their physical presence. Because incorporation fees and taxes provide states with revenue, there is competition among states that leads to the quick adoption of good practices (Romano, 1985). The most common way for these practices to be adopted is through an intermediary general purpose act, named the Model Business Corporation Act (MBCA). The MBCA is a prototype legal act maintained by the American Bar Association, capturing well-vetted principles of good corporate law. State legislatures use this prototype to develop their own state-level acts. As argued most prominently by La Porta et al. (1997), these improvements in corporate law should increase entrepreneurship through multiple channels, such as improving the willingness of entrepreneurs to engage with investors and increasing their prospects at raising debt. Furthermore, if the prior law contained inefficiencies that benefited a core number of constituents—i.e., leading to regulatory capture (Laffont and Tirole, 1991) — then the benefits should be larger for those outside of this group, such as women, minorities, and those outside the core city.

This paper provides an empirical assessment of the impact of adopting the first version of the MBCA—released in 1946—on regional entrepreneurship. Using a difference-in-differences approach, I study the number of new corporations created each year before and after the adoption of the MBCA in each state. Registering as a corporation is the legal procedure required to create a new firm (indeed, it is its filing that creates the firm). The process requires both a jurisdiction for 
the firm and a physical business location. Firms must register in their jurisdiction of incorporation and also in each state in which they engage in meaningful business activity. However, corporate law improvements only benefit firms if they occur in their jurisdiction. For example, New York entrepreneurs registered under New York jurisdiction do not see a direct benefit from improvements in Nevada law, even if they hold a large branch office in Nevada. Similarly, Massachusetts entrepreneurs registered under Delaware jurisdiction do not benefit directly from improvements in Massachusetts corporate law, even if that is their home state. This paper takes advantage of the fact that different firms in the same location may benefit differently from corporate law improvements to compare firm founding rates controlling for local business conditions and net out the effect of the law itself.

The main comparison is the rate of new registrations of local corporations relative to the control group of new registrations of firms headquartered in other states that expand into the state. The necessary assumption for this approach is that the omitted variables that increase entrepreneurship in the state, such as the local business cycle, make the state similarly more attractive for expanding firms. This paper begins by showing that this assumption appears valid in the data. While the introduction of the law is obviously not random, and there is significant endogeneity in the introduction of corporate laws even with two-way fixed effects (i.e., state and year $)^{1}$, once firm formation is measured relative to expanding firms from Delaware jurisdiction, the pre-trends become zero. The registration rate of firms in neighboring states, who are exposed to local economic cycles but not affected by corporate law changes, also changes from a pre-trend to zero. At a political level, the adoption of the MBCA appears unrelated to local politics such as

\footnotetext{
${ }^{1}$ The number of registrations shows visible pre-trends before the law and, consistent with the idea that this is driven by local economic shocks, the number of registrations in neighbor states (who do not enact the law) is also increasing.
} 
the timing of elections and the composition of the state legislature, or other actions improving the state business environment, such as banking deregulation (Kerr and Nanda, 2009). Taken together, this evidence suggests that the empirical approach controls for the necessary omitted variables.

I then estimate a substantial impact of corporate law improvements on entrepreneurship. The number of local corporations (the type most benefited by the MBCA) formed annually increases by $26 \%$ on average after a state's adoption. This effect comes about quickly, after three years of adoption, and persists for up to fifteen years. Yet, a meaningful portion of this increase is substitution from other firm types. Half of the main effect can be accounted for by reductions in either limited partnerships of local jurisdiction or in firms headquartered in the state but incorporated in Delaware. The net effect of corporate law is therefore about $13 \%$.

Several additional robustness tests support this result. The result remains stable when including additional controls for state business activity, such as employment and employment growth. They are also robust to using other sets of firms as the control group, such as including expansions from other jurisdictions (and not only Delaware) as the control category, and changing the control category to be the rate of registrations in firms local to neighbor states. They are also not sensitive to dropping all observations for states that have had the MBCA act for more than a decade. I then perform two validations focused on recent concerns raised on the estimation of two-way fixed effects models. The first is a concern over treatment heterogeneity which can bias, and even invert the sign of, the estimated average treatment effect (de Chaisemartin and D'Haultfœuille, 2020). Using the estimator by de Chaisemartin and D'Haultfœuille that corrects for this bias, shows virtually identical estimates. The second is an additional validation for the potential endogeneity of treatment. Here, I consider the instrumental variables approach of Freyaldenhoven et al. (2019) who show that given the availability of an imperfect proxy for an endogenous variable, such as the 
foreign (non-local) firm expansions I use as a control group, it is possible to use the forward lag of treatment instrumenting the proxy to control for this endogeneity. Once again, the effects are unchanged. Altogether, these validations emphasize the robustness of the main estimate to a series of potential concerns.

Finally, I present a placebo test using variation in the quality of corporate law implemented. To do so, I use historical accounts from the authors of the original MBCA that include their own assessment as to whether the MBCA was implemented well, or poorly, in different states. In contrast to the substantial main effect, which only used the full implementations of the MBCA, the effect for versions of the law that are implemented poorly is zero. This is consistent with the idea that increases in entrepreneurship are driven by an improvement in the quality of the law rather than the passage of a corporate act itself.

Next, I study heterogeneity across the level of development of corporate law in each state. The benefits of corporate law improvements to entrepreneurship must depend on the relative improvement compared to the local law. I find that states that have a smaller legal industry, and a lower density of incorporations in 1950 (as proxies for a poorer legal environment a-priori) benefit more. Western states, which had relatively less developed institutions at the time, also see a higher benefit. On the other hand, adopting the MBCA had a small and non-significant effect on states in the Midwest. These states were more developed at the time, and the Illinois corporate code had served as a starting point for writing the MBCA (the American Bar Association is located in Chicago). Thus, it is intuitive that adopting the MBCA would have no effect since the relative improvements in the legal environment were much lower.

In the final section, I use data from the U.S. Current Population Survey to move beyond firm registrations to study individuals instead. This data allows me to study the labor choices of 
individuals and consider heterogeneity across demographics. Using repeated cross-sections before and after the MBCA adoption with state and year fixed effects, I document that people in states who adopted the MBCA have higher self-employment, but no higher wage employment or labor force participation. These differences indicate that MBCA adoption increased entrepreneurship and not only firm registration. Furthermore, when considering the increase in self-employment across demographics, I find larger effects in groups that are more marginalized in the typical business environment of this time, including women, black, and those outside the central business district. These results suggest that by reducing regulatory uncertainty, the MBCA in turn reduced regulatory capture (Laffont and Tirole, 1991). The effect for individuals who just moved from out of state is zero, suggesting the MBCA did not promote any inter-state migration.

These results contribute to multiple areas of the literature on finance, law, and entrepreneurship.

The first is the large body of empirical work studying the impact of law on regional outcomes, both across states (Berkowitz and Clay, 2005) and across countries (Armour and Cumming, 2008; Djankov et al., 2002). While this literature initially studied long-run legal institutions (La Porta et al., 1998; Acemoglu and Johnson, 2005; Lerner and Schoar, 2005), it has more recently moved to investigate short-term variation using panels of countries to consider outcomes such as lending (Haselmann et al., 2009), investment (McLean et al., 2012; Brown et al., 2013), and innovation (Levine et al., 2017; Brown et al., 2013). Within the United States, a small number of papers have also used exogenous variation created by the forced change from tribal law to U.S. law in Native American areas to understand the long-run impact of U.S. legal institutions on the rule of law, financing, and sovereignty (Wellhausen et al., 2017; Brown et al., 2016).

Relative to these prior studies, this paper contributes to understanding the impact of the legal environment on regional activity in several ways. These include considering the direct effect of 
'good corporate law' in and of itself, without the contamination of other aspects of institutions that go beyond corporate law, such as culture or the quality of courts and the judicial system; focusing on state-level changes rather than cross-country comparisons; and studying entrepreneurship, an outcome well understood to be a key driver of regional economic growth (Haltiwanger et al., 2013).

Second, this paper contributes to the literature studying financial policies that motivate entrepreneurial ecosystems. Recent evidence suggests that policy has little impact on local entrepreneurship. For example, estimates of the effects of R\&D tax credits on entrepreneurship show that, initially, they mainly help existing firms (Agrawal et al., 2020; Lanahan and Feldman, 2018; Babina and Howell, 2018), and that they take many years to promote new firm entry (Fazio et al., 2020). Similarly, state tax credits for angel investing appear to have largely been unhelpful in propping up entrepreneurial activity and instead primarily increased investment in low-quality insider firms in the United States (Denes et al., 2020). ${ }^{2}$ Finally, Feldman (2001) presents a detailed case study of the U.S. Capitol region (the Washington D.C. area) to show that the catalyst event for the formation of this entrepreneurial ecosystem was the presence of 'pioneering entrepreneurs' who then created the necessary institutions as they grew, rather than direct ex-ante government intervention. Together, this evidence predicts weak or null effects of government policy in improving entrepreneurial entry over the short term. This paper, by contrast, documents one aspect of government policy that seems to positively impact entrepreneurship: the legal framework. Furthermore, consistent with Laffont and Tirole (1991) this paper presents suggestive evidence that by reducing regulatory uncertainty, the MBCA also reduced regulatory capture and its associated inequality.

The remainder of this paper proceeds as follows. Section 2 describes the Model Business

\footnotetext{
${ }^{2}$ However, Gonzalez Uribe and Paravasini (2019) show similar credit had a significant positive effect in the U.K.
} 
Corporation Act. Section 3 reviews the data. Section 4 is the empirical model. Section 5 reports the empirical results. Section 6 concludes.

\section{The Model Business Corporation Act}

The Model Business Corporation Act (MBCA) is a prototype legal act (i.e., a model) created by the American Bar Association to provide guidance to states seeking to improve their corporate code. Model acts are amalgamations of best practices in corporate law that legislative bodies (such as states or cities) can copy or adapt when developing their law. They are used extensively in the United States and often constitute significant guidance for state and municipal legislative improvements.

As the United States recovered from the war effort of the 1940s, inter-state commerce and population boomed, and most states found their corporate laws lacking the quality necessary to support the needs of a more sophisticated business community. The few exceptions to this were Delaware — a state that had already emerged as a location of choice for firms requiring sophisticated transactions - and some economically important states that had already developed complex law, such as New Jersey, Ohio, and New York.

Even though they faced a need for better corporate law, most states lacked the capabilities to create it. Some states were still in the process of achieving statehood themselves (e.g., Hawaii), and others either had such a small population or relied on citizen-legislators ${ }^{3}$ (who spend a large

\footnotetext{
${ }^{3}$ Citizen-legislators are legislators that spend the bulk of their time in 'citizen' (non-legislative) activities, such as professional jobs or businesses. Even though the U.S. federal government relies fully on 'professional-legislators' who get the bulk of their compensation from their legislative work, many U.S. states even today continue to work through citizen-legislators. Squire (2007) provides a measure of professionalism across state legislatures in the present day. MacRae (1954) provides an in-depth account of Massachusetts legislators' common activities during this paper's study period.
} 
portion of their time in non-legislative activities) that state knowledge of how to set up and design new corporate law was roughly non-existent.

To fill this need, the American Bar Association, a non-profit entity dedicated to developing legal practice and teaching standards, decided in 1943 to create the Model Business Corporation Act. The original Model Act was released in 1946 and revised in 1950 and 1953, after long periods of open comment from the Association's members (Campbell, 1956). The Model Act contained 145 sections, including:

The process of incorporation, corporate powers, corporate purposes, authorized shares, shareholder meetings, directors' meetings, dividends, directors' liabilities, charter amendments, the sale and mortgaging of assets, mergers and consolidations, dissolution, receivership, the admission and ouster of foreign corporations, annual reports, license fees and franchise taxes, and general provisions.

(Campbell, 1956)

States began to adopt it quickly. Maryland was the first in 1951, followed by Oregon (1953), Texas (1955), North Carolina (1955), and Wisconsin (1956). Fourteen more states adopted it over the next ten years.

The extent of adoption, however, was not always the same. In most cases, the adoption of the act was virtually 'complete' (in fact, often verbatim), in part due to the aforementioned preference for using the best practices as-is. However, in a small number of cases, states decided to adopt only portions of the act. The most notable one was North Carolina. As Campbell (1956), the lead author of the Model Act, notes:

In 1955 North Carolina adopted a new statute. While the published work of the North Carolina committee contains many references to, and credit lines for, the model act, the Section's committee feels that such a poor job was done in North Carolina that it rejects the thought of any kinship between the new North Carolina act and the model act.

Gibson and Freeman Jr (1967) concur and mention that the MBCA was incorporated only "to a lesser measure" in the acts of Maryland (1951), North Carolina (1955), Alabama (1959), and Connecticut (1959). 
Consistent with the important role of corporate law in the economic environment, these authors also emphasize the vast benefits for improved economic transactions provided by the MBCA. Reflecting on the new South Carolina law, Folk III (1962) mentions ${ }^{4}$ :

The prior law was no more than a collection of ad hoc provisions, enacted by the General Assembly as the need arose from time to time over a period of 150 years, and given the semblance of a corporate law only by their arrangement in the usual corporate law sequence. As a consequence, the prior law suffered from a remarkable combination of gaps, ambiguities, uncertainties, redundancies, and archaic restrictions with little or no bearing on contemporary problems. (p. 351)

Once this wave of adoption passed, the MBCA moved to a quasi-dormant state until it underwent a significant revision in 1983, with the release of the Revised Model Business Corporation Act (Goldstein and Hamilton, 1983). The present study focuses on the adoption of the original Model Act and its influence on local economic activity.

\section{Data}

This study takes advantage of several distinct datasets. The core data is a state-level panel measuring new firm formation across each state using historical business registration records procured through the Startup Cartography Project (Andrews et al., 2020). I add indicators of the introduction of new corporate acts modeled after the MBCA, built using historical articles published in The Business Lawyer and other outlets, and measures of state-level business activity through the U.S. Census County Business Patterns (CBP) data. Finally, I also employ in a separate analysis the U.S. Census Current Population Survey (CPS). I describe each data in turn.

\footnotetext{
${ }^{4}$ Additional quotes by some of these authors on the improvements provided by the MBCA are presented in the Appendix A.
} 


\subsection{Measuring Entrepreneurship Using Business Registration Records}

Measures of state entrepreneurship come from the business registration records of firms registered across U.S. states between 1946 when World War II ended, and 1983, when the Revised MBCA was introduced. Business registration is the act of legally establishing a new entity with which to conduct business. Between 1946 and 1983, states broadly-offered two types of registration to entrepreneurs: a corporation, which is a limited liability entity without pass-through taxation benefits; and a limited partnership, which is a pass-through entity with unlimited liability for the general partners. Registering their firm as a corporation or partnership offers several important benefits to entrepreneurs compared to remaining an unregistered firm (sole-proprietorship): it can provide limited liability in risk-taking, tax advantages, a common entity for shared ownership and management, and it is a practical necessity for any company that wishes to receive investment.

As is the case today, entrepreneurs registering a new firm in the mid-twentieth century were not required to register their company under the state jurisdiction where they lived, or where the company had its main business operations. Since the end of the 19th century, when the process of firm registration opened, a non-trivial number of new firms have been registered under Delaware jurisdiction, even when their principal headquarters are located elsewhere. This foreign (i.e., out of state $^{5}$ ) registration does not imply that those firms do not register in their local state: firms are also required to register as a foreign firm in every state in which they conduct meaningful business. ${ }^{6}$

I received data on all corporations and partnerships of both local and foreign jurisdictions through the Startup Cartography Project (Andrews et al., 2020). The Startup Cartography Project

\footnotetext{
${ }^{5}$ In U.S. corporate law, the term 'foreign firm' simply reflects one registered under a different state jurisdiction, and not a different country.

${ }^{6}$ Generally, state legislatures require all companies that either lease property, hire employees, or get a bank account to register in the local jurisdiction.
} 
is a project measuring the quality and quantity of entrepreneurship across U.S. regions in the present day. With a team of collaborators, we engaged in an effort to request and purchase business registration data from the Secretaries of State (or Commonwealth) of each state. Even though the Startup Cartography Project focuses on entrepreneurship after 1988, most states provided the full database of their registrations, allowing us to also observe earlier years. Specifically, I received information on registered firms for 46 states after excluding three states that did not provide data before 1988 - Illinois, Nebraska, and Pennsylvania — and excluding local Delaware firms, due to that state's unique nature in the U.S. firm registration process. ${ }^{7}$ The analysis in the present paper is limited to the data from firms founded between 1946 to 1983 . Limiting the time period to 1983 is also useful in that a different corporate law change - the introduction of limited liability companies (LLCs) — was starting to gain traction at this point since its invention by Wyoming in 1977, and it would go on to significantly alter the legal structure and incidence of U.S. firms in the follow-on decades. $^{8}$

I aggregate this data into a balanced panel of new firm registrations. Each observation includes several mutually exclusive measures of the number of firm registrations occurring in a given state and year. Local Corporations is the outcome variable of interest in most regressions. It represents the total number of new corporations registered in the local state jurisdiction in that state and year. This is the variable that the introduction of better corporate law should impact if corporate law does influence entrepreneurship. Local Partnerships represents the number of limited partnerships registered locally under the focal state's jurisdiction in a given year. While the MBCA also improved the quality of law for local limited partnerships, the relative improvement was higher

\footnotetext{
${ }^{7}$ Namely, while the entrepreneur usually chooses between a local firm and a Delaware firm in most states, these two choices are not available for firms located in Delaware, for obvious reasons.

${ }^{8}$ See Gazur (1995) for a detailed account of the adoption of the LLC and its impact.
} 
for corporations. From the entrepreneur's perspective, it is therefore not clear if the appeal of registering as a local partnership increases or decreases after MBCA adoption. Local Delaware is the yearly count of new firm registrations for firms that are local to the state but have chosen to register under Delaware jurisdiction rather than the jurisdiction of the state in which they are located. Foreign Delaware is the yearly count of registrations of firms that are not local to the state and register as they enter the state in the process of expansion. While the first three variables indicate entrepreneurship in the state, the fourth one does not and indicates only expanding firms.

Finally, I include four more alternative measures that proxy for the level of local business activity. The first three are business expansions from other states besides Delaware. New Jersey Firms, New York Firms, and Ohio Firms are the number of firms registered in each state from these three jurisdictions, which represent the most economically developed and institutionally advanced states during this period. The fourth measure, Neighbor State Corporations, is the total sum of corporations registered as local firms in the states directly neighboring the focal one. This is an additional proxy for the localized business activity occurring in a geographic area.

\subsection{Documenting MBCA Adoptions}

To record the year when states adopted the MBCA, I take advantage of historical articles authored in creating either the MBCA itself or the state-level acts. A particularly useful source was the volumes of The Business Lawyer. Published by the American Bar Association, The Business Lawyer is the top trade journal for corporate law and the main channel of public commentary on the MBCA. It includes articles written by the lead author of the MBCA, Whitney Campbell (Campbell, 1956), tallies of adoptions produced by the Association itself (American Bar Assoc., 1965), and 
articles by the authors of specific state acts (Gibson, 1956). I complemented this with law review articles by authors of individual pieces of legislation, especially the comprehensive accounts by George Gibson (Gibson, 1956, 1958; Gibson and Freeman Jr, 1967) on the introduction of the Virginia Corporation Law, and by Stanley Siegel (Siegel, 1970) on the Michigan Business Corporation Act. Gibson and Freeman Jr (1967) is particularly useful as it includes a list of all the states that adopted the MBCA up to 1967 and the year of adoption. Finally, I also found value in the more recent retrospective of the MBCA by Booth (2000), and the foreword on the state of corporate law in 1983 by Goldstein and Hamilton (1983) who wrote the Revised MBCA.

Table 1 documents the year of adoption of the MBCA in each adopting state, divided into two groups, complete and partial adoptions. I define two variables from this data. MBCA Adopted is a binary variable equal to 1 full for adoptions of the MBCA and 0 otherwise, and $M B C A$ Partial Adoption is a binary variable equal to 1 for partial or 'poor' adoptions of the MBCA and 0 otherwise.

\subsection{Employment from County Business Patterns}

I control for employment by using digitized versions of the County Business Patterns (CBP). CBP is an annual series provided by the U.S. Census documenting business activity by industry at different levels of geographic granularity. I consider CBP data by SIC sector starting in 1956. I use manually digitized versions from 1956 to $1973,{ }^{9}$ and the CBP data created by Eckert et al. (2020) afterward. The CBP was not done by the U.S. Census for all years, skipping the years 1957, $1958,1960,1961$, and 1963. I use the value in the latest available previous year for these years.

\footnotetext{
${ }^{9}$ I am thankful to Dan Gross for sharing the digitized records collected from the physical copies of the CBP data from 1956 to 1973.
} 


\subsection{Individual Data from the Current Population Survey}

Finally, I downloaded the Current Population Survey (CPS) records form the Integrated Public Use Micro Series (IPUMS) database. IPUMS offers CPS information for the March version of the CPS starting in years 1962. I downloaded all observations from 1962 to 1989. For each response, I included their location, whether they are self-employed, whether they are a wage worker, whether they are in the labor force, their age, sex, race, metropolitan area, where in the metro area they are located, and whether they arrived to the state in the last year.

Between the years 1968 to 1976, the CPS recorded some regions, but not all, as groups of states, rather than individual states, such as "Arkansas-Oklahoma" and "South Carolina-Georgia". Since the shock in this paper is purely at the state level, I exclude these observations. Finally, to avoid concerns of wrong comparisons in difference-in-differences (Goodman-Bacon, 2021), I focus only on data from states adopting the MBCA during the time period of study and include only observations from ten years before this adoption to twenty years after.

\subsection{Summary Statistics}

Table 2 presents the summary statistics for each variable in the state-level data using business registrations. There are 1,748 observations. Twenty-two percent of the observations have a new corporate act that adopted the MBCA, and six percent have a partial MBCA adoption. The number of annual local corporations and partnerships founded in a state is on average 3709 and 264, respectively. There is substantial skewness in these measures driven by the skewed distribution of population and economic activity across U.S. states. The number of local and foreign Delaware companies is lower but meaningful. 
Figure 1 provides a sense of the evolution of firm registrations in the U.S. by plotting each variable over time with the $y$-axis on a log scale. We observe a clear log-linear trend in the data, consistent with firm formation growing on a balanced growth path on par with the broader U.S. economy. This log-linearity supports the idea of including variables in their log form in the regression analysis. The slope of the curves reflects annual average growth on the firm formation rate between $1.1 \%$ and $1.9 \%$, depending on the measure. Delaware local firm counts grew at $1.1 \%$ while Delaware foreign firms grew at $1.2 \%$, a difference that is not statistically significant in the data.

Table A1 provides the summary statistics of the CPS dataset. There are 192,483 observations in the data.

\section{Empirical Model}

The empirical approach focuses on the rate at which new local corporations are founded relative to the incidence of foreign Delaware firms, which are used as a proxy measure for the underlying economic activity of a region. The dependent variable of interest is the log ratio between local corporations and foreign Delaware firms. Specifically, for each state $s$ at year $t$, I estimate

$$
\log \left(\frac{\text { Local Corporations }_{s, t}}{\text { Foreign Delaware }_{s, t}}\right)=\alpha+\beta \times M_{s, t}+\gamma_{s}+\delta_{t}+\epsilon_{s, t}
$$

Where $M_{s, t}$ is an indicator equal to one if the state has adopted the MBCA (and zero otherwise), $\gamma_{s}$ is a state fixed effect, $\delta_{t}$ is a year fixed effect, and $\epsilon_{s, t}$ is random noise. Standard errors are

clustered at the state level. The advantage of this specification is that it forces the coefficient of 
Foreign Delaware $_{s, t}$ to one, thus allowing $\beta$ to be interpreted as the change in the registration of local corporations relative to the registration of foreign Delaware registrations for that state and year.

When year-by-year coefficients are reported, I instead estimate a coefficient $\beta_{\tau}$ where $\tau$ indicates the number of years after the new act goes into effect, taking a negative value for years before the act. The baseline category in these models is the year right before the act is adopted (i.e., $\tau=-1$, the last full year the prior corporate law is in effect). The estimating equation is then

$$
\log \left(\frac{\text { Local Corporations }_{s, t}}{\text { Foreign Delaware }_{s, t}}\right)=\alpha+\beta_{\tau} \times M_{s, \tau}+\gamma_{s}+\delta_{t}+\epsilon_{s, t}
$$

\subsection{Validation of Pre-Trends}

I assess whether this empirical approach controls for the endogeneity of the MBCA adoption graphically in Figure 2. Here, I report the annual coefficients of a two-way fixed effects model around the introduction of new acts adopting the MBCA, using the year before their introduction as the baseline. The top figure plots the yearly coefficients of local corporations registered including state and year fixed effects. There are noticeable pre-trends in the data that accentuate closer to the adoption of the new corporate law. This suggests that laws are adopted at the top of the business cycle. The bottom figure is the rate of foreign Delaware firms. There is a similar, though noisier, pre-trend before the introduction of corporate law, which peaks at the same time. The rate of foreign Delaware firms then decreases after the introduction of the law. ${ }^{10}$ In short, while there appears to be endogeneity in the law, this endogeneity is well captured by other control categories

\footnotetext{
${ }^{10}$ Figure A2 reports the same analysis using the number of corporations in neighbor states instead. The results are similar to those of foreign Delaware firms.
} 
that are not affected by the law, so that studying the rate of firm registrations relative to these control categories could account for this endogeneity.

\subsection{Other Omitted Variables: Policy and Politics}

Controlling for foreign Delaware firms allows addressing changes in the endogenous role of business cycles and state growth in precipitating the adoption of the MBCA. However, there are other potential avenues for bias. A key concern is related to trends in policy or politics across

locations. For example, the adoption of the MBCA could be correlated with the adoption of other business-friendly policies such as taxes (Fazio et al., 2020) or banking deregulation (Kerr and Nanda, 2009). Then, the impact of these policies would be wrongly attributed to the MBCA. Similarly, changes in political cycles may precipitate the adoption of the MBCA in ways that would also relate to other business environment outcomes.

I consider these concerns before delving into the analysis.

Conceptually, while changes in policy and politics appear as plausible omitted variables, it is not obvious given the institutional nature of corporate law updates. The process of updating corporate law is a slow process of several years that is led by the legal bar association and practicing lawyers of a state, hoping to improve the practice of corporate law. Because it is led by practicing lawyers, it is not tightly linked to other business environment areas that are more tightly linked to politics. For example, George Gibson, who led the MBCA-adopting act in Virginia, was a partner at the prestigious Richmond-based firm Hunton \& Williams, LLP. Similarly, the South Carolina 1962 update was driven by Ernest Folk III who worked initially in the Antitrust Division of the U.S. Dept. of Justice, and then was a professor of corporate law (playing also a key role in the 
update of Delaware Corporate Law in 1967, and creating the Revised Model Corporation Act in 1983). Furthermore, an important component in the adoption of the MBCA was the existence of a Model Act to be incorporated, rather than simply the need for better corporate law. Indeed, both Gibson and Folk emphasize that the laws of their states had been in need of updating for a long time, but it had previously proved a difficult task due to the difficulties of finding a good model law to build on. Appendix A provides a long and detailed description of the types of changes that the MBCA brought into Virginia and South Carolina. As can be appreciated, the changes are about the 'details' of corporate law and do not appear connected to generally perceived as politically sensitive topics.

Empirically, the endogeneity of policy and politics also appears not to be important. To study this, in Figure A8, I repeat the empirical approach of the paper using the entry of state deregulation laws documented in Kerr and Nanda (2009) as the dependent variable. The adoption of the MBCA does not predict any type of state deregulation (de-novo intrastate, M\&A intrastate, or interstate). In Figure A9, I consider instead the political environment surrounding the adoption of the MBCA using the state-level dataset created by Weir and Martin (2012). The adoption of the MBCA does not predict the timing of elections, whether the state has a republican governor, or the number of legislators in either the upper or lower house of the state legislature. 


\section{Results}

\subsection{Main Estimates}

I now proceed to the main estimates of the benefit of adopting the MBCA on regional entrepreneurship. Figure 3 presents the coefficients of the main regression (equation (2)) graphically. The pre-trends are now effectively zero. The coefficients then turn positive and significant two years after the act is introduced and remain stable at an average level of $23 \%$ for up to 15 years. Figures A3 to A5 report this same graph in three other variations: including a 15-year pre-period panel, adding one to the number of corporations to avoid dropping any zeroes, and adding firms from other states to the control category. The results are virtually unchanged. There appears to be a meaningful benefit of adopting the MBCA on state-level entrepreneurship.

Table 3 estimates the effect using a two-way fixed effects regression with the preferred dependent variable. Columns (1) and (2) are preliminary models that suggest the unconditional correlation between adopting MBCA and regional entrepreneurship is negative. This makes sense because the states in most need of standardizing their corporate law were smaller and younger. Column (3) is the main estimate. The coefficient is 0.24 and statistically significant. It suggests that improvements in corporate law led to an average increase of $26 \%$ in firm formation during the period. ${ }^{11}$

Columns (4) to (6) introduce a series of controls based on reported employment levels in the County Business Patterns (CBS). Column (4) controls for total employment. The coefficient is positive and significant, close to 1 . This is reassuring as the amount of employed population in a location should have a very close link to total firm formation. Yet, while positive, introducing this

$$
{ }^{11} e^{.24}-1=0.26 .
$$


control does not change the main effect of the MBCA.

Column (5) controls for employment in the manufacturing, mining, and finance sectors. Column (6) also includes two-year lags for all employment measures, in essence allowing to control for their growth rate. Once again, the main effect is effectively unchanged.

Table 4 studies substitution patterns in firm formation from the MBCA adoption. Columns (1) and (2) are variations of equation (1) using local partnerships and local Delaware firms instead in the numerator. The coefficients are negative though noisy. The introduction of new corporate law did not increase the rate of local partnerships, or the rate of new firms of Delaware jurisdiction headquartered in the state. This is reassuring and serves as a placebo test. Since the new law did not target these firm types, we should not see them increase.

However, the negative coefficients also suggest that there could have been substitution from these firm types into corporations. If this is the case, then some of the increase in corporations may not represent net new firms, but rather a shift in the choice of registration for some firms. To study this possibility, columns (3) to (5) change the denominator of the dependent variable by replacing these local categories in the denominator. This allows the coefficient to represent the change in corporations relative to these other groups. The coefficients all hover around 0.4. Since this is about twice the magnitude of Table $3,{ }^{12}$ it implies that about half of all new corporations are substituting from other types, rather than net new firms. Furthermore, since Delaware firms are usually considered more growth-oriented firms, and partnerships less growth-oriented, than corporations (Andrews et al., 2019), the similarity of coefficients suggests that this substitution pulled from both sides of the quality distribution.

\footnotetext{
${ }^{12}$ i.e., $\left(e^{.4}-1\right) /\left(e^{.23}-1\right) \approx 2$.
} 


\subsection{Robustness Tests}

Table 5 reports a series of robustness tests including different control variables, subsamples, and dependent variables. Column (1) focuses more closely on the changes around the timing of treatment by dropping all observations for treated states that occur ten years after treatment. The main estimate is now more precise and remains very close in magnitude to the main estimate. Columns (2) and (3) use two other proxies for the local economy instead of the count of foreign Delaware firms as the denominator in the dependent variable. Column (2) brings together the different measures of foreign firms in the data-foreign Delaware, New Jersey, New York, and Ohio. The coefficient is practically the same. Column (3) uses the number of corporations in neighbor states as the reference category. This is a different proxy for local economic conditions that does not use the registrations in the treated state. The coefficient is positive and slightly larger in magnitude.

Column (4) is a placebo test that considers the impact of treatment on the rate of corporations in neighboring states. If the effect I document is driven by unobservables that are correlated across states, then the MBCA may also show a positive treatment effect on the number of corporations in neighbors. Reassuringly, the effect is zero.

Figure A6 considers more directly well-known challenges with two-way fixed effects models. To do so, I implement the estimator of de Chaisemartin and D'Haultfœuille (2020), who show that if there is treatment heterogeneity in a two-way fixed effects model, then some individual treatment effects could have negative weights biasing (and even changing the sign of) the estimated average treatment effect. The coefficients using their estimator are strikingly close to the main estimate. Concerns about bias induced through treatment heterogeneity are not first order in this data. 
Table 6 considers an instrumental variable approach building on Freyaldenhoven et al. (2019). These authors show that in a panel setting with binary treatment and a proxy for potential confounders, the forward lags of treatment used as an instrument on the proxy can purge the effect of the confounders. In this paper, I have throughout used foreign Delaware firms as a proxy for local business cycles, making the Freyaldenhoven et al approach applicable. Column (1) reports the OLS regression for comparability. Column (2) implements the instrumental variable regression. The estimator used is LIML rather than OLS since the instrument is slightly weak, with a reported F-statistic of 2.8. The resulting estimates are once again the same.

\subsection{The Quality of the MBCA Adoption}

Table 7 considers heterogeneity across the quality of the law implemented. Recall from Section 2 that while most states adopted the MBCA fully, which has been the focus of the analysis so far, there are some other states that only did a partial or poor implementation of the MBCA. Table 7 reports in columns (1) and (2) the effect of these implementations on entrepreneurship. The coefficient is noisy and negative in sign. Figure 4 repeats this regression by plotting annual coefficients for these partial MBCA adoptions. We do not observe any pre-trends, but we also observe no positive increase subsequent to the new law. Incomplete or poor adoptions of the MBCA did not increase entrepreneurship.

\subsection{Heterogenity by State Legal Development and Timing}

I next study the heterogeneity across states focusing on the level of development of the legal institutions at the beginning of the period. The goal is to assess whether states with less developed 
legal institutions saw a larger benefit from adopting the MBCA. Such evidence would be consistent with an improvement in the legal framework leading to higher entrepreneurship rather than other confounding factors.

In Table 8, I report a series of heterogeneity analyses diving states by more and less developed legal institutions. For each test, we observe larger effects for states with less developed legal institutions, consistent with the idea that those states experiencing a larger improvement saw larger benefits from the law.

Columns (1) and (2) split the data based on the size of the law industry. Specifically, using the 1950 U.S. Census 1-percent sample, I estimate the share of employed individuals in industry 841 (Legal Services) and split the states above and below the median of this value. The effects are substantially higher for those states with a smaller legal industry. While the coefficient in states below the median of industry size is 0.319 and significant at the $5 \%$ level, the coefficient for those above the median is only 0.109 and not significant.

Columns (3) and (4) use the incidence of incorporation in 1950 instead as a measure of the sophistication of the legal industry by splitting states based on the number of local corporations by employed individuals established in that year. The effect is 0.369 and significant for states with a lower level of corporations per capita, but only 0.0429 and not significant for those with more corporations per capita.

Finally, columns (5) and (6) focus on the state's size proxied through the total level of employed individuals, assuming that larger states generally require more complex corporate code. The effects are qualitatively similar to the previous ones, though the differences in magnitude are smaller.

Table 9 focuses on heterogeneity across locations. After World War II, the Midwest was an industrial powerhouse for the U.S. and a leading economic region, while the West was still in its 
ongoing process of settlement and the South was still largely an agricultural economy. The benefits of the MBCA on entrepreneurship are observed mostly in the (new states of) the West, and to a lesser extent on the South, with a minimal effect in the Midwest. This result is also consistent with the precedence of the law, since the Illinois corporate law was the original template from which the MBCA was developed.

Table 10 reports the coefficients across distinct periods. Column (1) considers only those states that adopted the MBCA before 1960, column (2) contains those that adopted it between 1960 and 1969, and column (3) excludes the six states that adopted it in 1965. The results appear broadly quite similar, though perhaps slightly higher for earlier adopters.

\subsection{Heterogeneity Based on State-Level Industry Structure}

Next, I assess heterogeneity in the benefits of adoption of the MBCA based on the industrial characteristics of the state that adopts it. To do so, I consider the state structure in 1956 and the relationship of employment in each SIC sector to the MBCA. Specifically, I measure the share of all employment that belongs to each SIC sector in the County Business Patterns data, and include the interaction of this share to the MBCA law.

Appendix Figure A10 reports, for each SIC sector, the marginal effect of the MBCA at the 10th and 90th percentiles of the values of this distribution. There are no differences based on the size of the sector for agriculture, finance, retail trade, wholesale trade, and services. However, states with higher mining share or higher construction share do see larger effects, as do those with a lower manufacturing share.

The larger effect for mining and construction makes intuitive sense. These two sectors require 
some of the largest investments for a project and they have some of the longest timelines, so that good corporate law can prove particularly useful. The differences for manufacturing are less intuitive. However, manufacturing at this time was clustered in the Midwest, which was already shown in the previous section to have no treatment effects. Understanding the role of industrial composition better is an important area for future work.

\subsection{Self-Employment and Distributional Effects}

Finally, I consider the impact of the MBCA on self-employment using data from the Current Population Survey (CPS). Using the CPS allows me to move beyond business registrations to labor force surveys and demographics, assessing the role of the MBCA on labor choices and its distributional impact.

Table 11 reports repeated cross-sections of the CPS data, including year and state fixed effects, and reports the relationship of adopting the MBCA to different outcomes. I also include fixed effects for age, race, sex, the individual cities (MSAs), and whether the person just moved. To focus on comparisons of states that have adopted vs not (Goodman-Bacon, 2021), I consider only observations in states from ten years before MBCA adoption to twenty years after. Standard errors are clustered at the state level.

Columns (1) through (3) study the impact of adopting the MBCA on different types of labor market outcomes. Column (1) reports whether the individual reports being self-employed. The effect is positive and significant. Being in a state that has adopted the MBCA is associated with an increase of 2.2 percentage points in being self-employed. Columns (2) and (3) consider the relationship of the MBCA to being a wage worker or not in the labor force. Here, the effects are 
instead zero. These effects suggest that the MBCA increases the probability of entrepreneurship, while not increasing meaningfully other margins in the labor market.

I then report heterogeneity across different dimensions to try to understand better who benefits from the MBCA. I focus on individually interacted coefficients (the main effect of each interaction is already included in all fixed effects), to measure the treatment effect of the MBCA individually for each group.

Columns (4) and (5) are demographics. Female and black individuals see larger effects from the MBCA than men or white individuals. Column (6) considers the level of urbanization. The smallest effect is for those already located in the central city, while all others in less urban areas see a larger impact. These results suggest a pattern where the MBCA increases access more for individuals less core to the economic activities in the region, consistent with the mechanisms in Laffont and Tirole (1991) where reducing regulatory uncertainty also reduces regulatory capture.

Finally, column (7) considers a different mechanism: whether the MBCA attracted migrants or helped those recently arriving. We see all the effect is limited to those that did not recently move into the state. The MBCA did not induce the migration of entrepreneurs.

\section{Conclusion}

I studied how corporate law influences entrepreneurship by considering the experiences of U.S. states in the mid-twentieth century when many states improved corporate law by adopting the Model Business Corporation Act. The results reveal that the new law on average increased corporations by $26 \%$, around half of which were substitutions from other firms, and the rest of which were net-new firms. The effects are larger in states with more rudimentary institutions and 
are zero for partial adoptions of the MBCA. The largest effects are concentrated in women, black individuals, and those located outside the central city.

At a policy level, these results suggest that the adequate tuning and updating of law is an essential aspect of a functioning economy. Legislating well matters. It is useful to highlight that the law studied here was a compendium of nationwide best practices developed by a single organization (the American Bar Association), which the individual state corporate laws copied closely. This implies that good corporate law principles have commonality across jurisdictions, albeit within the limited heterogeneity offered by U.S. states. The experience of the MBCA further shows that a significant hurdle to the introduction of better law is the cost of developing this law and that guidelines, best practices, templates, and model acts, can make this process more efficient.

These insights are only the first set of results in a rich avenue of inquiry. More work is needed to fully understand the role of law in the development of financing and entrepreneurship and the way in which the legal environment can support the process of creative destruction and ultimately drive development and economic growth.

\section{References}

Daron Acemoglu and Simon Johnson. Unbundling institutions. Journal of political Economy, 113 (5):949-995, 2005.

Ajay Agrawal, Carlos Rosell, and Timothy Simcoe. Tax credits and small firm r\&d spending. American Economic Journal: Economic Policy, 2020.

American Bar Assoc. Recent adoptions of the model business corporation act, 1965.

Raymond J Andrews, Catherine Fazio, Jorge Guzman, Yupeng Liu, and Scott Stern. The startup cartography project. Working Paper, 2019.

Raymond J Andrews, Catherine Fazio, Jorge Guzman, Yupeng Liu, and Scott Stern. The Startup Cartography Project. Working Paper, 2020. 
John Armour and Douglas Cumming. Bankruptcy Law and Entrepreneurship. American Law and Economics Review, 10(2):303-350, 08 2008. ISSN 1465-7252. doi: 10.1093/aler/ahn008. URL https://doi.org/10.1093/aler/ahn008.

Tania Babina and Sabrina T Howell. Entrepreneurial spillovers from corporate $r \& d$. Technical report, National Bureau of Economic Research, 2018.

Daniel Berkowitz and Karen Clay. American civil law origins: implications for state constitutions. American Law and Economics Review, 7(1):62-84, 2005.

Richard A. Booth. A chronology of the evolution of the mbca. The Business Lawyer, 56(1):63-67, 2000.

James R Brown, Gustav Martinsson, and Bruce C Petersen. Law, stock markets, and innovation. The Journal of Finance, 68(4):1517-1549, 2013.

James R Brown, J Anthony Cookson, and Rawley Z Heimer. Law and finance matter: Lessons from externally imposed courts. The Review of Financial Studies, 30(3):1019-1051, 2016.

Whitney Campbell. The model business corporation act. The Business Lawyer, pages 98-110, 1956.

Robert D Cooter and Hans-Bernd Schäfer. Solomon's Knot. Princeton University Press, 2011.

Clément de Chaisemartin and Xavier D'Haultfœuille. Two-way fixed effects estimators with heterogeneous treatment effects. American Economic Review, 110(9):2964-96, September 2020. doi: 10.1257/aer.20181169. URL https://www.aeaweb.org/articles?id= 10.1257 / aer.20181169.

Matthew R Denes, Sabrina T Howell, Filippo Mezzanotti, Xinxin Wang, and Ting Xu. Investor tax credits and entrepreneurship: Evidence from us states. Technical report, National Bureau of Economic Research, 2020.

Simeon Djankov, Rafael La Porta, Florencio Lopez-de Silanes, and Andrei Shleifer. The regulation of entry. The quarterly Journal of economics, 117(1):1-37, 2002.

Fabian Eckert, Teresa C Fort, Peter K Schott, Natalie J Yang, et al. County business patterns database. 2020.

Catherine Fazio, Jorge Guzman, and Scott Stern. The impact of state-level research and development tax credits on the quantity and quality of entrepreneurship. Economic Development Quarterly, 34(2):188-208, 2020. doi: 10.1177/0891242420920926. URL https ://doi . org/10.1177/0891242420920926.

Maryann P. Feldman. The Entrepreneurial Event Revisited: Firm Formation in a Regional Context. Industrial and Corporate Change, 10(4):861-891, 12 2001. ISSN 0960-6491. doi: 10.1093/icc/ 10.4.861. URL https://doi.org/10.1093/icc/10.4.861.

Ernest L Folk III. The model act and the south carolina corporation law. SCL Rev., 15:275, 1962. 
Simon Freyaldenhoven, Christian Hansen, and Jesse M. Shapiro. Pre-event trends in the panel event-study design. American Economic Review, 109(9):3307-38, September 2019. doi: 10. 1257/aer.20180609. URL http: / / www . aeaweb. org/articles?id=10 . 1257 / aer. 20180609.

Wayne M Gazur. The limited liability company experiment: Unlimited flexibility, uncertain role. Law \& Contemp. Probs., 58:135, 1995.

George D Gibson. The virginia corporation law of 1956. Virginia Law Review, pages 445-487, 1956.

George D Gibson. Virginia's experience with the model business corporation act. The Business Lawyer, pages 706-717, 1958.

George D Gibson and George C Freeman Jr. A decade of the model business corporation act in virginia. Virginia Law Review, pages 1396-1423, 1967.

Elliot Goldstein and Robert W. Hamilton. The revised model business corporation act. The Business Lawyer, 38(3):1019-1029, 1983.

Juanita Gonzalez Uribe and Daniel Paravasini. How sensitive is young firm investment to the cost of outside equity? evidence from a uk tax relief. Working Paper, 2019.

Andrew Goodman-Bacon. Difference-in-differences with variation in treatment timing. Journal of Econometrics, 225(2):254-277, 2021.

John Haltiwanger, Ron S Jarmin, and Javier Miranda. Who creates jobs? small versus large versus young. Review of Economics and Statistics, 95(2):347-361, 2013.

Rainer Haselmann, Katharina Pistor, and Vikrant Vig. How law affects lending. The Review of Financial Studies, 23(2):549-580, 2009.

William R Kerr and Ramana Nanda. Democratizing entry: Banking deregulations, financing constraints, and entrepreneurship. Journal of Financial Economics, 94(1):124-149, 2009.

Rafael La Porta, Florencio Lopez-de Silanes, Andrei Shleifer, and Robert W Vishny. Legal determinants of external finance. The Journal of Finance, 52(3):1131-1150, 1997. ISSN 00221082, 15406261. URL http: / /www. jstor.org/stable/2329518.

Rafael La Porta, Florencio Lopez-de Silanes, Andrei Shleifer, and Robert W Vishny. Law and finance. Journal of political economy, 106(6):1113-1155, 1998.

Jean-Jacques Laffont and Jean Tirole. The politics of government decision-making: A theory of regulatory capture. The quarterly journal of economics, 106(4):1089-1127, 1991.

Lauren Lanahan and Maryann P Feldman. Approximating exogenous variation in r\&d: Evidence from the kentucky and north carolina sbir state match programs. Review of Economics and Statistics, 100(4):740-752, 2018. 
David S Landes, Joel Mokyr, and William J Baumol. The invention of enterprise: Entrepreneurship from ancient Mesopotamia to modern times. Princeton University Press, 2012.

Josh Lerner and Antoinette Schoar. Does legal enforcement affect financial transactions? the contractual channel in private equity. The Quarterly Journal of Economics, 120(1):223-246, 2005.

Ross Levine, Chen Lin, and Lai Wei. Insider trading and innovation. The Journal of Law and Economics, 60(4):749-800, 2017.

Duncan MacRae. The role of the state legislator in massachusetts. American Sociological Review, 19(2):185-194, 1954. ISSN 00031224. URL http: / / www · jstor.org/stable/ 2088400.

R David McLean, Tianyu Zhang, and Mengxin Zhao. Why does the law matter? investor protection and its effects on investment, finance, and growth. The Journal of Finance, 67(1):313-350, 2012.

Roberta Romano. Law as a product: some pieces of the incorporation puzzle. Journal of Law, Economics, \& Organization, 1(2):225-283, 1985.

Roberta Romano. The genius of American corporate law. American Enterprise Institute, 1993.

Stanley Siegel. The proposed michigan business corporation act. University of Michigan Journal of Law Reform, 4(2):161-179, 1970.

Peverill Squire. Measuring state legislative professionalism: The squire index revisited. State Politics \& Policy Quarterly, 7(2):211-227, 2007.

Margaret Weir and Isaac William Martin. State tax revolt data set, 1960-1992. Inter-university Consortium for Political and Social Research [distributor], 2012. URL https://www . icpsr.umich.edu/web/ICPSR/studies/34273.

Rachel L Wellhausen et al. Sovereignty, law, and finance: Evidence from american indian reservations. Quarterly Journal of Political Science, 12(4):405-436, 2017.

Oliver E Williamson. Markets and hierarchies: analysis and antitrust implications: a study in the economics of internal organization. University of Illinois at Urbana-Champaign's Academy for Entrepreneurial Leadership Historical Research Reference in Entrepreneurship, 1975. 
Figure 1: Number of New Registrations by Year in Sample States

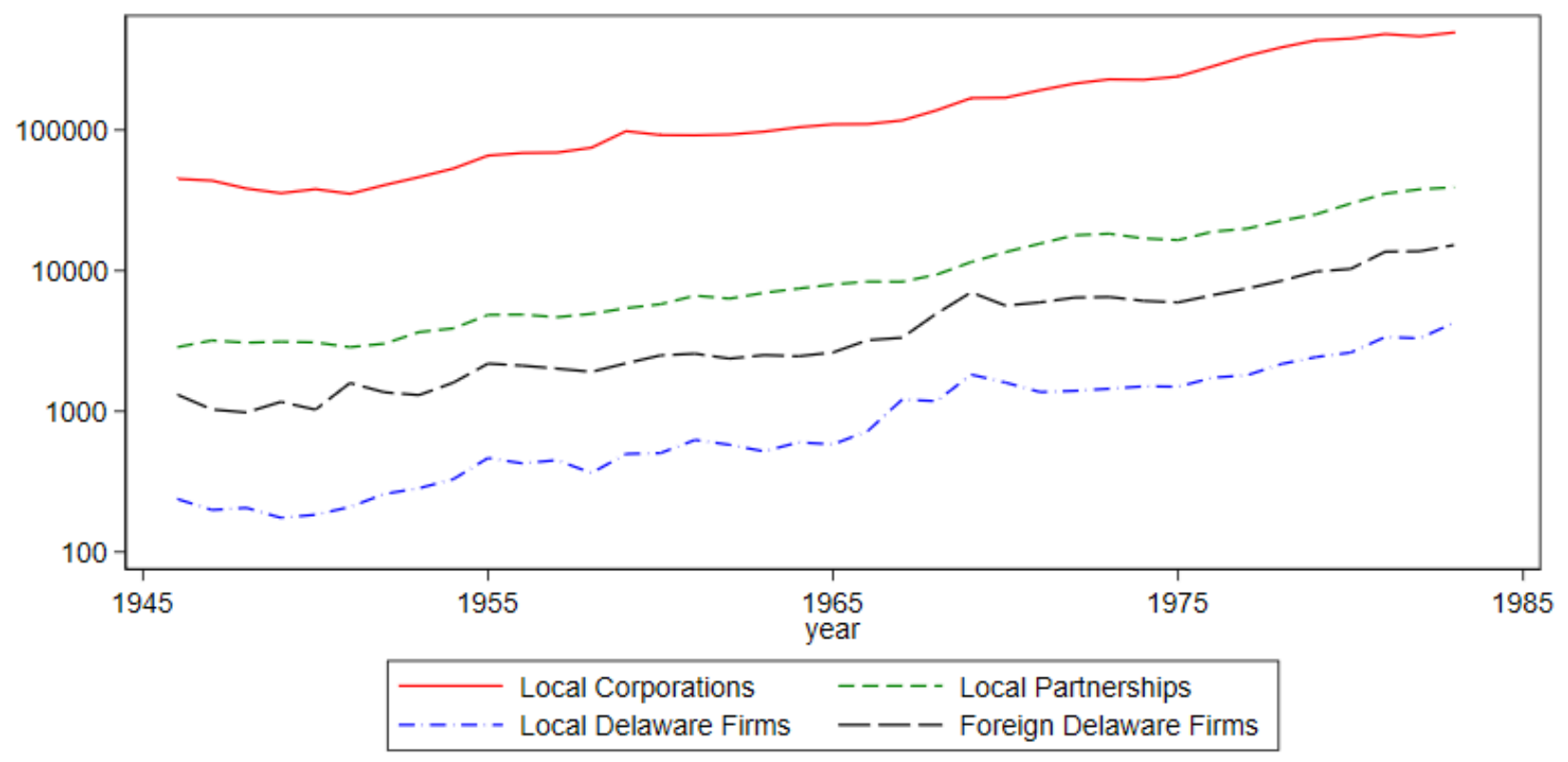

Notes: The figure presents the annual number of new firms registered in the U.S. in four mutually exclusive groups of firms. The $\mathrm{y}$ axis is in a log-scale to reflect the exponential growth of population and the economy in this time-period. The observed log-linearity supports well the idea of using the log of firm counts as the dependent variable. 
Figure 2: Graphical Estimates on Endogenous Policy
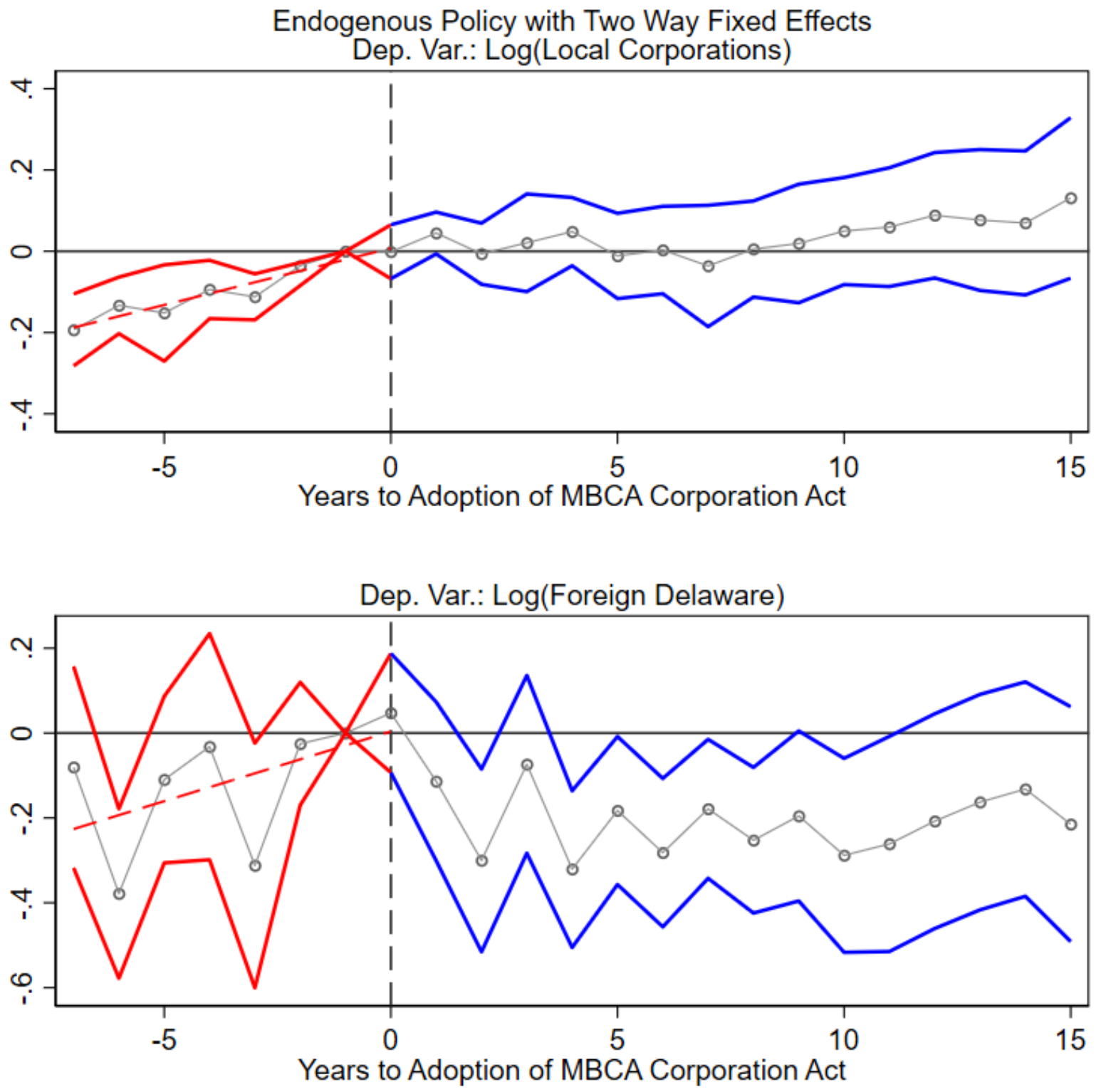

Notes: The top panel reports the annual coefficients for the number of local corporations- the variable that is likely to be impact by the new law-before and after the law is adopted. The points represent the estimated coefficient and the lines are the 95 percent confidence interval. The baseline category is the year before the new law starts. The red dashed line represents the fitted values of all coefficients from $t=-7$ to $t=0$. Controls for the log of total employment, and of employment in the sectors of finance, manufacturing, and mining are included, as well as year and state fixed effects included. Standard errors clustered by state. 
Figure 3: Main Estimate

\section{Dep. Var.: Log(Local Corporations/Delaware Foreign)}

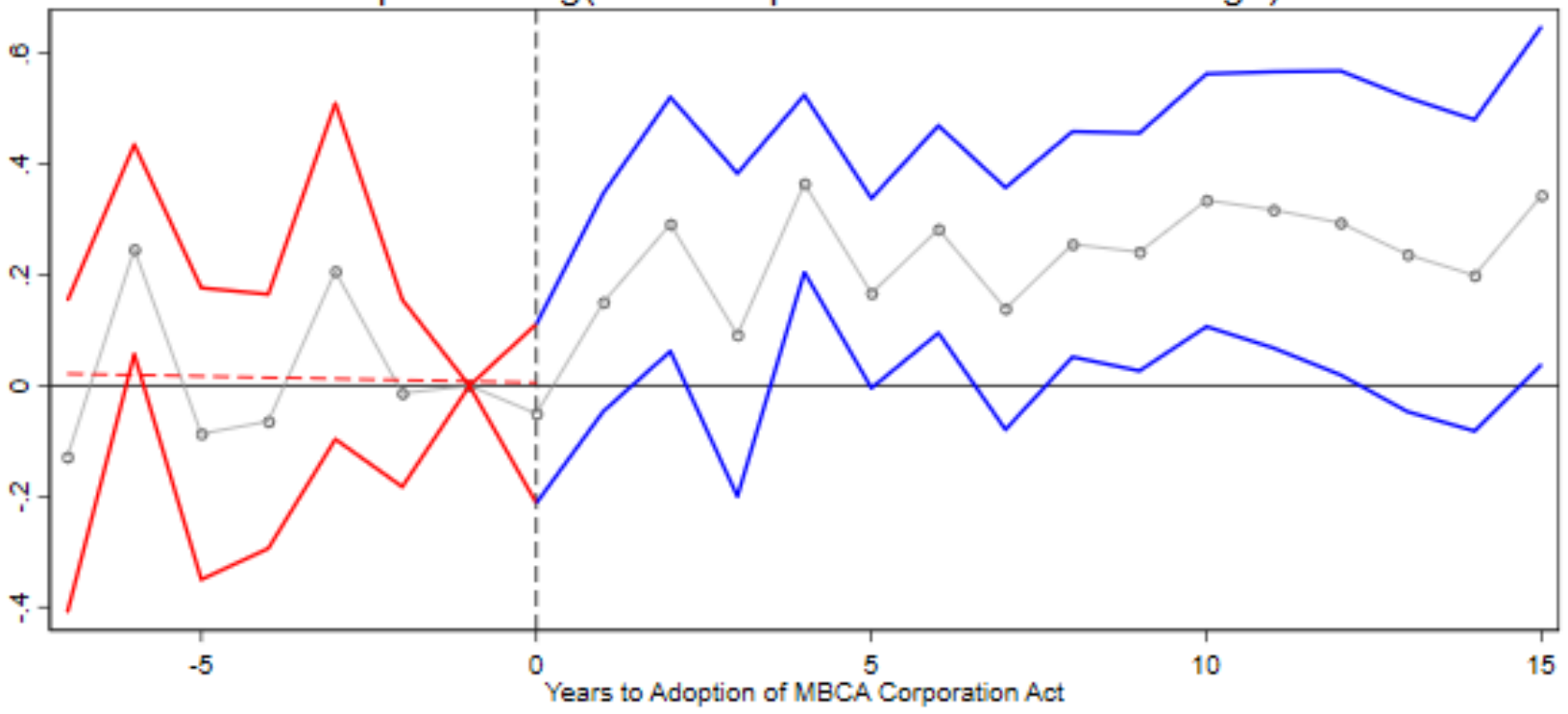

Notes: The figure reports the annual coefficients using the relative increase of local corporations compared to Delaware foreign registrations. The baseline category is one year before the law goes into effect. The red dashed line represents the fitted values of all coefficients from $t=-7$ to $t=0$. Controls for the $\log$ of total employment, and of employment in the sectors of finance, manufacturing, and mining are included, as well as year and state fixed effects included. Standard errors clustered by state. 
Figure 4: Partial MBCA Adoption

Poor and Incomplete MBCA Adoptions.

Dependent Variable: Log(Local Corporations/Delaware Foreign)

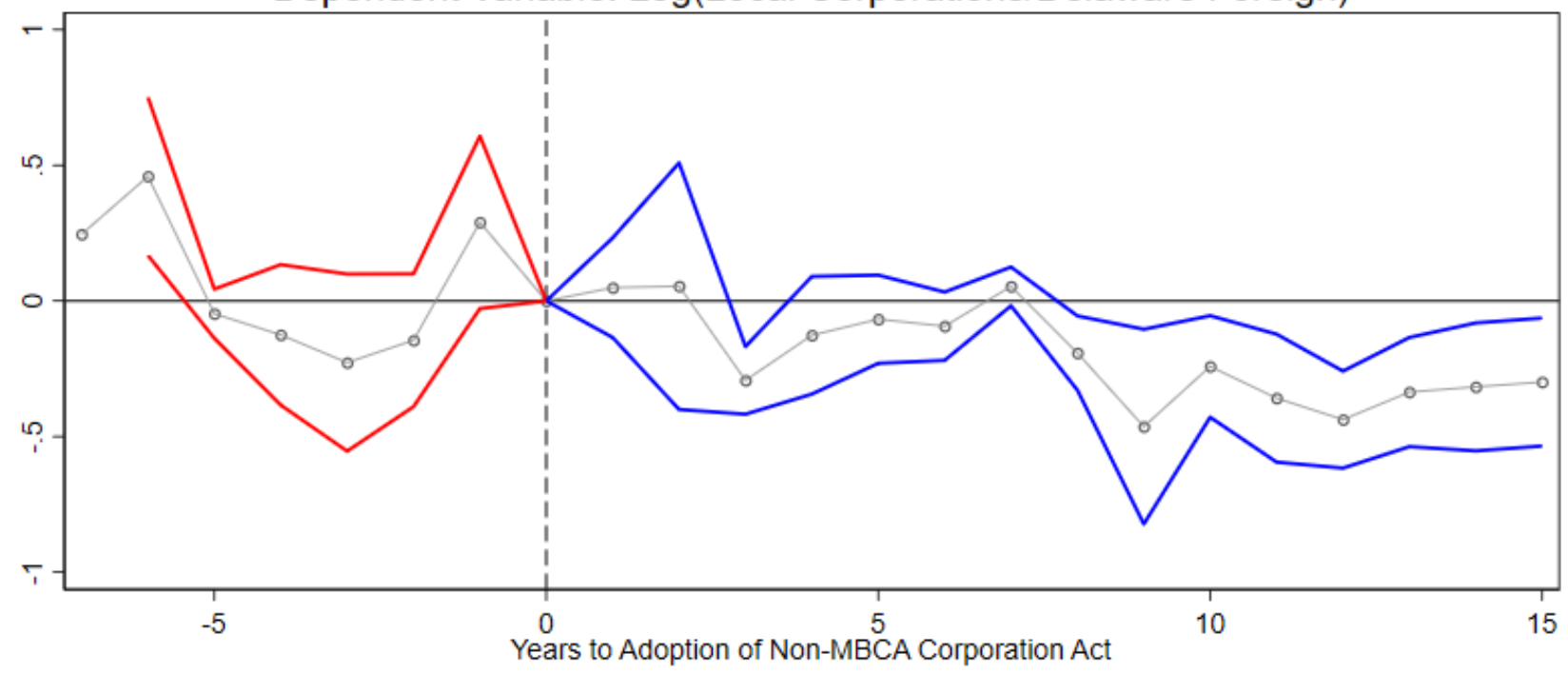

Notes: The figure reports the coefficients of the main model of Section 4 for acts that did not implement the MBCA fully, the measurement of which is described in Section 2. Consistent with the principle that law leads to entrepreneurship, there is no effect from the act. Controls for the log of total employment, and of employment in the sectors of finance, manufacturing, and mining are included, as well as year and state fixed effects included. Standard errors clustered by state. 
Table 1: Adoption of Model Business Corporation Act

\begin{tabular}{lccc}
\hline \hline \multicolumn{3}{c}{ Adoptions of MBCA } \\
\hline State & Year & Source & In Sample \\
\hline Oregon & 1953 & Campbell (1956) & Yes \\
Texas & 1955 & Campbell (1956) & Ces \\
Virginia & 1956 & Gibbell (1956) & Yes \\
Alaska & 1957 & Gibson and Freeman Jr (1967) & Yes \\
North Dakota & 1957 & Gibson and Freeman Jr (1967) & Yes \\
Colorado & 1958 & Gibson and Freeman Jr (1967) & Yes \\
Iowa & 1959 & Gibson and Freeman Jr (1967) & Yes \\
Utah & 1961 & Gibson and Freeman Jr (1967) & Yes \\
Wyoming & 1961 & Gibson and Freeman Jr (1967) & Yes \\
Mississippi & 1962 & Gibson and Freeman Jr (1967) & Yes \\
South Carolina & 1962 & Gibson and Freeman Jr (1967) & Yes \\
Nebraska & 1963 & Gibson and Freeman Jr (1967) & No \\
Missouri & 1965 & Gibson and Freeman Jr (1967) & Yes \\
Pennsylvania & 1965 & Gibson and Freeman Jr (1967) & No \\
Wisconsin & 1965 & Gibson and Freeman Jr (1967) & Yes \\
Arkansas & 1965 & American Bar Assoc. (1965) & Yes \\
Washington & 1965 & American Bar Assoc. (1965) & Yes \\
South Dakota & 1965 & American Bar Assoc. (1965) & Yes \\
Michigan & 1971 & Siegel (1970) & Yes \\
& & & \\
& Other Corporation & Acts only Partially Building from MBCA & \\
\hline Maryland & 1951 & Gibson and Freeman Jr (1967) & Yes \\
North Carolina & 1955 & Campbell (1956), Gibson and Freeman Jr (1967) & Yes \\
Alabama & 1959 & Gibson and Freeman Jr (1967) & Yes \\
Connecticut & 1959 & Gibson and Freeman Jr (1967) & Yes \\
\hline
\end{tabular}


Table 2: Summary statistics of state by year dataset.

\begin{tabular}{|c|c|c|c|c|}
\hline Variable & Details & Mean & Std. Dev. & $\mathbf{N}$ \\
\hline \multicolumn{5}{|l|}{ MBCA Measures } \\
\hline MBCA Adopted & $\begin{array}{l}1 \text { if the state has previously done a full adoption of } \\
\text { the MBCA and } 0 \text { otherwise. }\end{array}$ & 0.22 & 0.42 & 1748 \\
\hline MBCA Partial Adoption & $\begin{array}{l}1 \text { if the state has previously done a partial adoption } \\
\text { of the MBCA and } 0 \text { otherwise. }\end{array}$ & 0.06 & 0.24 & 1748 \\
\hline \multicolumn{5}{|l|}{ Startup Cartography Measures } \\
\hline Local Corporations & $\begin{array}{l}\text { The number of corporations of the state's local } \\
\text { jurisdiction registered in a state and year. }\end{array}$ & 3709.35 & 8704.46 & 1748 \\
\hline Local Partnerships & $\begin{array}{l}\text { The number of partnerships of the state's local } \\
\text { jurisdiction registered in a state and year. }\end{array}$ & 263.5 & 1099.21 & 1748 \\
\hline Local Delaware & $\begin{array}{l}\text { The number of local firms registered under } \\
\text { Delaware jurisdiction in a state and year. }\end{array}$ & 24.72 & 60.01 & 1748 \\
\hline Foreign Delaware & $\begin{array}{l}\text { The number of foreign (other state) firms registered } \\
\text { under Delaware jurisdiction in a state and year. }\end{array}$ & 101.55 & 194.42 & 1748 \\
\hline Neighbor State Corporations & $\begin{array}{l}\text { The number of firms registered in all neighboring } \\
\text { states in each year. }\end{array}$ & 13631.48 & 18529.45 & 1748 \\
\hline Ohio Firms & $\begin{array}{l}\text { The number of firms from Ohio jurisdiction } \\
\text { registered in a state and year. }\end{array}$ & 188.83 & 1472.65 & 1748 \\
\hline New Jersey Firms & $\begin{array}{l}\text { The number of firms from New Jersey jurisdiction } \\
\text { registered in a state and year. }\end{array}$ & 200.64 & 1776.5 & 1748 \\
\hline New York Firms & $\begin{array}{l}\text { The number of firms from New York jurisdiction } \\
\text { registered in a state and year. }\end{array}$ & 21.36 & 56.09 & 1748 \\
\hline Log(Local Corp./Foreign Del.) & $\begin{array}{l}\text { The } \log \text { ratio of local corporations to foreign } \\
\text { Delaware firms. }\end{array}$ & 3.26 & 1.04 & 1712 \\
\hline Log(Local Part./Foreign Del.) & $\begin{array}{l}\text { The } \log \text { ratio of local partnerships to foreign } \\
\text { Delaware firms. }\end{array}$ & -0.21 & 2.07 & 1333 \\
\hline Log(Local Del./Foreign Del.) & $\begin{array}{l}\text { The log ratio of local Delaware firms to foreign } \\
\text { Delaware firms. }\end{array}$ & -1.57 & 1.33 & 1208 \\
\hline \multicolumn{5}{|l|}{ CBP Measures } \\
\hline Log(Total Emp.+1) & Total employment in a state and year. & 13.17 & 1.17 & 1748 \\
\hline Log(Manufacturing Emp. +1 ) & $\begin{array}{l}\text { Total employment in the manufacturing sector in a } \\
\text { state and year. }\end{array}$ & 11.89 & 1.5 & 1748 \\
\hline Log(Mining Emp.+1) & $\begin{array}{l}\text { Total employment in the mining sector in a state } \\
\text { and year. }\end{array}$ & 8.59 & 1.56 & 1748 \\
\hline Log(Finance Emp. +1$)$ & $\begin{array}{l}\text { Total employment in the finance sector in a state } \\
\text { and year. }\end{array}$ & 10.31 & 1.24 & 1748 \\
\hline
\end{tabular}

Notes: Data is state by year spanning the years 1946 to 1983 for 47 U.S. states. 
Table 3: Main Estimate

\begin{tabular}{|c|c|c|c|c|c|c|c|}
\hline & $(1)$ & $(2)$ & $(3)$ & $(4)$ & $(5)$ & $(6)$ & $(7)$ \\
\hline MBCA Adopted & $\begin{array}{c}-0.261 \\
(0.225)\end{array}$ & $\begin{array}{c}-0.196 \\
(0.253)\end{array}$ & $\begin{array}{l}0.235^{*} \\
(0.126)\end{array}$ & $\begin{array}{c}0.209^{*} \\
(0.107)\end{array}$ & $\begin{array}{c}0.209^{*} \\
(0.107)\end{array}$ & $\begin{array}{c}0.219^{* *} \\
(0.101)\end{array}$ & $\begin{array}{c}0.230^{* *} \\
(0.0921)\end{array}$ \\
\hline Log(Total Employment +1$)$ & & & & $\begin{array}{l}1.025^{* *} \\
(0.203)\end{array}$ & $\begin{array}{l}1.025^{\text {** }} \\
(0.203)\end{array}$ & $\begin{array}{c}0.395 \\
(0.278)\end{array}$ & $\begin{array}{c}0.152 \\
(0.144)\end{array}$ \\
\hline Log(Manufacturing Employment +1) & & & & & & $\begin{array}{c}0.198 \\
(0.224)\end{array}$ & $\begin{array}{c}0.854^{* *} \\
(0.236)\end{array}$ \\
\hline Log(Mining Employment +1 ) & & & & & & $\begin{array}{c}-0.0299 \\
(0.0732)\end{array}$ & $\begin{array}{c}-0.0316 \\
(0.0543)\end{array}$ \\
\hline $\log ($ Finance Employment +1$)$ & & & & & & $\begin{array}{c}0.570^{*} \\
(0.339)\end{array}$ & $\begin{array}{c}-0.161 \\
(0.368)\end{array}$ \\
\hline L2.Log(Total Employment +1$)$ & & & & & & & $\begin{array}{c}0.466^{* *} \\
(0.203)\end{array}$ \\
\hline L2.Log(Manufacturing Employment +1 ) & & & & & & & $\begin{array}{c}-0.738^{* *} \\
(0.231)\end{array}$ \\
\hline L2.Log(Mining Employment+1) & & & & & & & $\begin{array}{c}0.0330 \\
(0.0573)\end{array}$ \\
\hline L2.Log(Finance Employment +1$)$ & & & & & & & $\begin{array}{c}0.524^{*} \\
(0.280)\end{array}$ \\
\hline State Fixed-Effects & No & No & Yes & Yes & Yes & Yes & Yes \\
\hline Year Fixed-Effects & No & Yes & Yes & Yes & Yes & Yes & Yes \\
\hline Observations & 1712 & 1712 & 1712 & 1712 & 1712 & 1712 & 1627 \\
\hline$R^{2}$ & 0.011 & 0.038 & 0.825 & 0.846 & 0.846 & 0.848 & 0.855 \\
\hline
\end{tabular}

OLS model .Dependent Variable is Log(Local Corporations/Delaware Foreign) Standard errors clustered at the state level. Significance denoted as: ${ }^{*} \mathrm{p}<0.10,{ }^{* *} \mathrm{p}<0.05,{ }^{* * *} \mathrm{p}<0.01$.

Table 4: Substitution from Other Outcomes.

\begin{tabular}{lccccc}
\hline \hline & $(1)$ & $(2)$ & $(3)$ & $(4)$ & $(5)$ \\
& $\log \left(\frac{\text { LocalPart. }}{\text { ForeignDel. }}\right)$ & $\log \left(\frac{\text { LocalDel. }}{\text { ForeignDel. }}\right)$ & $\log \left(\frac{\text { LocalCorps. }}{\text { LocalPart. }}\right)$ & $\log \left(\frac{\text { LocalCorps. }}{\text { LocalDel. }}\right)$ & $\log \left(\frac{\left.\begin{array}{c}\text { LocalCorps } \\
\text { LocalPart. }+ \text { LocalDel. }\end{array}\right)}{}\right.$ \\
\hline MBCA Adopted & -0.254 & -0.137 & $0.396^{*}$ & 0.456 & 0.433 \\
& $(0.390)$ & $(0.197)$ & $(0.203)$ & $(0.375)$ & $(0.266)$ \\
\hline Observations & 1333 & 1208 & 1214 & 1354 & 1597 \\
$R^{2}$ & 0.726 & 0.789 & 0.732 & 0.719 & 0.777 \\
\hline \hline
\end{tabular}

OLS model. Dependent variables are constructed relative to the number of Foreign Delaware firms. Columns (1) to (3) replace local corporations from the main dependent variable with local partnerships (Col (1)), local Delaware firms $(\mathrm{Col}(2))$, and the neighbor state local corporations (Col (3)). State and year fixed effects are included. Standard errors clustered at the state level. Significance denoted as: ${ }^{*} \mathrm{p}<0.10,{ }^{* *} \mathrm{p}<0.05,{ }^{* * *} \mathrm{p}<0.01$. 
Table 5: Robustness Tests.

\begin{tabular}{lcccc}
\hline \hline & $(1)$ & $(2)$ & $(3)$ & $(4)$ \\
& $\begin{array}{c}\text { Subsample } \\
\text { Drop 10 years } \\
\text { after treatment }\end{array}$ & $\log \left(\frac{\text { LocalCorps. }}{\text { ForeignDel. }+N Y+O H+N J}\right)$ & Log $\left(\frac{\text { LocalCorps. }}{\text { NeighborCorps. }}\right)$ & Log $\left(\frac{\text { NeighborCorps. }}{\text { ForeignDel. }}\right)$ \\
\hline MBCA Adopted & $0.232^{* *}$ & $0.237^{*}$ & $0.381^{* *}$ & 0.0183 \\
& $(0.103)$ & $(0.132)$ & $(0.167)$ & $(0.145)$ \\
\hline Observations & 1511 & 1727 & 1746 & 1712 \\
$R^{2}$ & 0.834 & 0.871 & 0.931 & 0.902 \\
\hline \hline
\end{tabular}

OLS model. Column (1) drops all states after they have been treated for 10 years using $\log (\operatorname{Local}$ Corporations/Foreign Delaware) as the dependent variable. Column (2) includes firms from New York, Ohio, and New Jersey to the denominator count of all foreign firms. Column (3) uses a different proxy for the local economic cycle, the total number of local corporations in neighbor states. State and year fixed effects included in all regressions. Standard errors clustered at the state level. Significance denoted as: ${ }^{*} \mathrm{p}<0.10,{ }^{* *} \mathrm{p}<0.05$, $* * * \mathrm{p}<0.01$.

Table 6: Robustness Test: Absolute Change in Local Corporations.

\begin{tabular}{lcc}
\hline \hline & $(1)$ & $\begin{array}{c}(2) \\
\text { OLS }\end{array}$ \\
& & $\begin{array}{c}\text { Instrumental Variables } \\
\text { Freyaldenhoven et al (2019) } \\
\text { LIML }\end{array}$ \\
\hline MBCA Adopted & $0.222^{* *}$ & $0.240^{*}$ \\
& $(0.104)$ & $(0.133)$ \\
Log(Foreign Delaware) & $0.221^{* *}$ & 1.055 \\
& $(0.0507)$ & $(0.665)$ \\
\hline Observations & 1712 & 1666 \\
$R^{2}$ & 0.114 & -1.185 \\
Kleibergen-Paap Weak Ident. F-Stat & & 3.046 \\
\hline \hline
\end{tabular}

OLS model. The dependent variable is Log)(Local Corporations) and foreign Delaware firms are included as a control rather than the preferred specification that puts them as a ratio. Column (1) is the OLS model. Column (2) implements the approach in Freyaldenhoven et al (2019) in which an endogenous control is instrumented by the forward lag of the treatment variable (i.e., $M B C A$ Adopted). State and fixed effects included in all regressions. Standard errors clustered at the state level. Significance denoted as: ${ }^{*} \mathrm{p}$ $<0.10,{ }^{* *} \mathrm{p}<0.05,{ }^{* * *} \mathrm{p}<0.01$.

Table 7: Placebo Test. Poor and Incomplete MBCA Adoptions.

\begin{tabular}{lcc}
\hline \hline & $(1)$ & $(2)$ \\
& $\log \left(\frac{\text { LocalCorps. }}{\text { ForeignDel. }}\right)$ & $\log \left(\frac{\text { LocalCorps. }}{\text { ForeignDel. }+N Y+O H+N J}\right)$ \\
\hline MBCA Partial Adoption & -0.302 & -0.200 \\
& $(0.309)$ & $(0.201)$ \\
\hline Observations & 1712 & 1727 \\
$R^{2}$ & 0.823 & 0.869 \\
\hline \hline
\end{tabular}

OLS model. Columns (1) and (2) are placebo tests using ther adoption of corporate acts that are not the MBCA act. State and year fixed effects included in all regressions. Standard errors clustered at the state and year level. Significance denoted as: ${ }^{*} \mathrm{p}<0.10,{ }^{* *} \mathrm{p}<0.05,{ }^{* * *} \mathrm{p}<0.01$. 
Table 8: Heterogeneity by Development of State Institutions in 1950.

\begin{tabular}{|c|c|c|c|c|c|c|}
\hline & $\begin{array}{c}(1) \\
\text { Subsample } \\
\text { Below Median } \\
\text { Law Industry } \\
\text { Size }\end{array}$ & $\begin{array}{c}(2) \\
\text { Subsample } \\
\text { Above Median } \\
\text { Law Industry } \\
\text { Size }\end{array}$ & $\begin{array}{c}\text { Subsample } \\
\text { Below Median } \\
\text { Corps. per Emp. }\end{array}$ & $\begin{array}{c}(4) \\
\text { Subsample } \\
\text { Above Median } \\
\text { Corps. per Emp. }\end{array}$ & $\begin{array}{l}\text { Subsample } \\
\text { Below Median } \\
\text { Total Emp. }\end{array}$ & $\begin{array}{c}(6) \\
\text { Subsample } \\
\text { Above Median } \\
\text { Total Emp. }\end{array}$ \\
\hline MBCA Adopted & $\begin{array}{l}0.319^{* *} \\
(0.117)\end{array}$ & $\begin{array}{c}0.109 \\
(0.160)\end{array}$ & $\begin{array}{l}0.369^{* *} \\
(0.176)\end{array}$ & $\begin{array}{l}0.0429 \\
(0.121)\end{array}$ & $\begin{array}{l}0.282^{* *} \\
(0.136)\end{array}$ & $\begin{array}{c}0.204 \\
(0.128)\end{array}$ \\
\hline $\begin{array}{l}\text { Observations } \\
R^{2}\end{array}$ & $\begin{array}{c}851 \\
0.864\end{array}$ & $\begin{array}{c}861 \\
0.836\end{array}$ & $\begin{array}{c}860 \\
0.776\end{array}$ & $\begin{array}{c}852 \\
0.886\end{array}$ & $\begin{array}{c}840 \\
0.820\end{array}$ & $\begin{array}{c}872 \\
0.783\end{array}$ \\
\hline
\end{tabular}

OLS model. Dependent variable is Log(Local Corporations/Foreign Delaware). Columns (1) and (2) use the 1950 census 1-percent data and split states based on the average share of employed people who work in the law industry. All regressions include state and year fixed effects and control for the $\log$ of total employment, manufacturing employment, mining employment, and finance employment. Standard errors are clustered at state level. Significance denoted as: $* \mathrm{p}<0.10$, ** $\mathrm{p}<0.05,{ }^{* * *} \mathrm{p}<0.01$.

Table 9: Heterogeneity by State Region.

\begin{tabular}{|c|c|c|c|}
\hline & $\begin{array}{c}(1) \\
\text { Subsample } \\
\text { South }\end{array}$ & $\begin{array}{c}(2) \\
\text { Subsample } \\
\text { West }\end{array}$ & $\begin{array}{c}(3) \\
\text { Subsample } \\
\text { Midwest }\end{array}$ \\
\hline MBCA Adopted & $\begin{array}{r}0.276 \\
(0.169)\end{array}$ & $\begin{array}{c}0.609^{* *} \\
(0.213)\end{array}$ & $\begin{array}{c}0.0711 \\
(0.156)\end{array}$ \\
\hline $\begin{array}{l}\text { Observations } \\
R^{2} \\
\end{array}$ & $\begin{array}{r}454 \\
0.817 \\
\end{array}$ & $\begin{array}{c}439 \\
0.835 \\
\end{array}$ & $\begin{array}{c}337 \\
0.853 \\
\end{array}$ \\
\hline $\begin{array}{l}\text { OLS model. } \\
\text { Corporations } / \\
\text { confederate sta } \\
\text { Utah, Idaho, } \\
\text { Carlifornia, an } \\
\text { Iowa, Michiga } \\
\text { Dakota, and } \\
\text { and year fixed } \\
\text { state level. Si } \\
<0.05, * * * \text { p }\end{array}$ & $\begin{array}{l}\text { Dependen } \\
\text { Foreign Delau } \\
\text { tes. West inc } \\
\text { Alaska, H } \\
\text { d Washington } \\
\text { n, Minnesota } \\
\text { Visconsin. Al } \\
\text { effects. Stand } \\
\text { gnificance den } \\
\text { 0.01. }\end{array}$ & $\begin{array}{l}\text { variable } \\
\text { are). Soutl } \\
\text { ludes Colora } \\
\text { awaii, Neva } \\
\text { State. Midw } \\
\text { Missouri, } \\
\text { regressions } \\
\text { ard errors ar } \\
\text { oted as: * }\end{array}$ & $\begin{array}{l}\text { is } \log (\text { Local } \\
\text { includes all } \\
\text { do, Wyoming, } \\
\text { da, Oregon, } \\
\text { est is Indiana, } \\
\text { Ohio, South } \\
\text { include state } \\
\text { e clustered at } \\
<0.10,{ }^{* *} p\end{array}$ \\
\hline
\end{tabular}

Table 10: Heterogeneity by Time of Adoption of MBCA.

\begin{tabular}{lrcc}
\hline \hline & \multicolumn{1}{c}{$(1)$} & $(2)$ & $(3)$ \\
& $\begin{array}{c}\text { Subsample } \\
\text { Adopted 1950-1959 }\end{array}$ & $\begin{array}{c}\text { Subsample } \\
\text { Adopted 1960-1969 }\end{array}$ & $\begin{array}{c}\text { Subsample } \\
\text { Excluding 1965 }\end{array}$ \\
\hline MBCA Adopted & $0.382^{*}$ & 0.229 & $0.281^{* *}$ \\
& $(0.218)$ & $(0.139)$ & $(0.136)$ \\
\hline Observations & 1338 & 1421 & 1599 \\
$R^{2}$ & 0.818 & 0.842 & 0.815 \\
\hline \hline
\end{tabular}

OLS model. Dependent variable is Log(Local Corporations/Foreign Delaware). Column (1) considers only states that adopted the MBCA between 1950 and 1959. Column (2) those that adopted between 1960 and 1969. Column (3) excludes the six states that adopted the MBCA in 1965. All regressions also include states that did not adopt the MBCA. State and year fixed effects included. Standard errors are double clustered at state and year levels. Significance denoted as: ${ }^{*} \mathrm{p}<0.10,{ }^{* *} \mathrm{p}<0.05,{ }^{* * *} \mathrm{p}<0.01$. 
Table 11: MBCA and Self-Employment in the Current Population Survey

\begin{tabular}{|c|c|c|c|c|c|c|c|}
\hline & $\begin{array}{c}(1) \\
\text { Self Emp. }\end{array}$ & $\begin{array}{c}(2) \\
\text { Wage Worker }\end{array}$ & $\begin{array}{c}(3) \\
\text { Not in the } \\
\text { Labor Force }\end{array}$ & $\begin{array}{c}(4) \\
\text { Self Emp. }\end{array}$ & $\begin{array}{c}(5) \\
\text { Self Emp. }\end{array}$ & $\begin{array}{c}(6) \\
\text { Self Emp. }\end{array}$ & $\begin{array}{c}(7) \\
\text { Self Emp. }\end{array}$ \\
\hline MBCA Adopted & $\begin{array}{l}0.0224^{* *} \\
(0.00280)\end{array}$ & $\begin{array}{l}-0.0231 \\
(0.0115)\end{array}$ & $\begin{array}{c}-0.0111 \\
(0.00724)\end{array}$ & & & & \\
\hline \multicolumn{8}{|l|}{ Gender } \\
\hline Male $\times$ MBCA Adopted & & & & $\begin{array}{l}0.0176^{* *} \\
(0.00316)\end{array}$ & & & \\
\hline Female $\times$ MBCA Adopted & & & & $\begin{array}{l}0.0267^{* *} \\
(0.00601)\end{array}$ & & & \\
\hline \multicolumn{8}{|l|}{ Race (White and Black Only) } \\
\hline White $\times$ MBCA Adopted & & & & & $\begin{array}{c}0.0208^{* *} \\
(0.00260)\end{array}$ & & \\
\hline Black $\times$ MBCA Adopted & & & & & $\begin{array}{c}0.0329^{* *} \\
(0.00906)\end{array}$ & & \\
\hline \multicolumn{8}{|l|}{ Urban vs Rural } \\
\hline Not identifiable $\times$ MBCA Adopted & & & & & & $\begin{array}{c}0.0389^{* *} \\
(0.00998)\end{array}$ & \\
\hline Not in metro area $\times$ MBCA Adopted & & & & & & $\begin{array}{l}0.0206^{* *} \\
(0.00634)\end{array}$ & \\
\hline Central city $\times$ MBCA Adopted & & & & & & $\begin{array}{l}0.0180^{* *} \\
(0.00354)\end{array}$ & \\
\hline Outside central city $\times$ MBCA Adopted & & & & & & $\begin{array}{l}0.0270^{* *} \\
(0.00487)\end{array}$ & \\
\hline Central city status unknown $\times$ MBCA Adopted & & & & & & $\begin{array}{l}0.0454^{* *} \\
(0.0124)\end{array}$ & \\
\hline \multicolumn{8}{|l|}{ Migration } \\
\hline Moved Last Year $=0 \times$ MBCA Adopted & & & & & & & $\begin{array}{c}0.0229^{* *} \\
(0.00285)\end{array}$ \\
\hline Moved Last Year $=1 \times$ MBCA Adopted & & & & & & & $\begin{array}{l}0.00401 \\
(0.0104)\end{array}$ \\
\hline Observations & 192483 & 192483 & 192483 & 192483 & 189549 & 192483 & 192483 \\
\hline$R^{2}$ & 0.075 & 0.270 & 0.469 & 0.075 & 0.076 & 0.076 & 0.075 \\
\hline
\end{tabular}

OLS model. Sample is all data from the U.S. Current Population Survey (CPS). Fixed effects for state, year, age (individual years), race, gender, and metro area (individual cities). Standard errors double clustered at tstate levels. Significance denoted as: $* \mathrm{p}<0.10, * * \mathrm{p}<0.05$, $* * * \mathrm{p}<0.01$. 
Appendix 
Figure A1: Endogenous Policy: 15 Year Pre-period
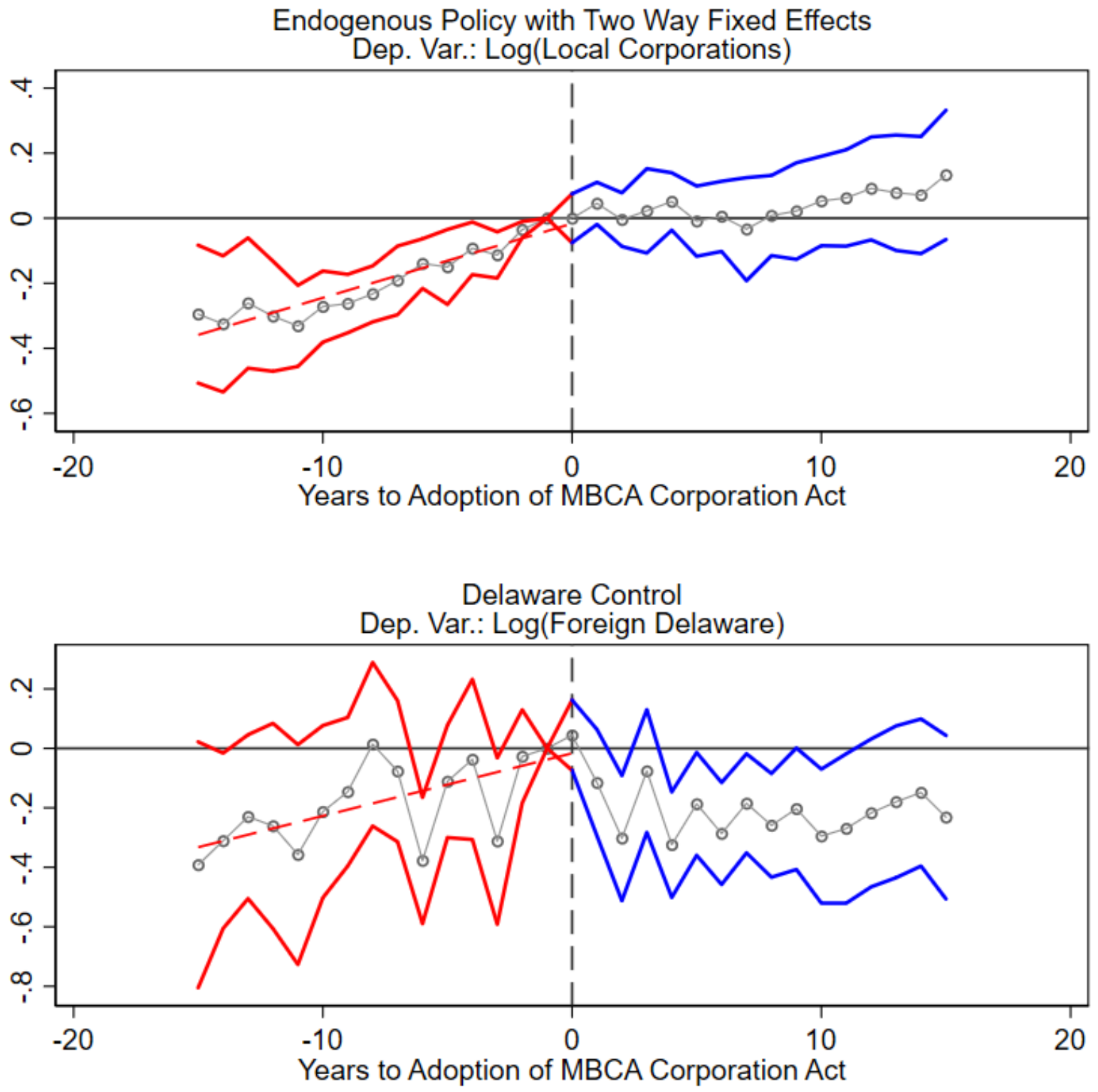
Figure A2: Endogenous Policy: Alternative Measure.

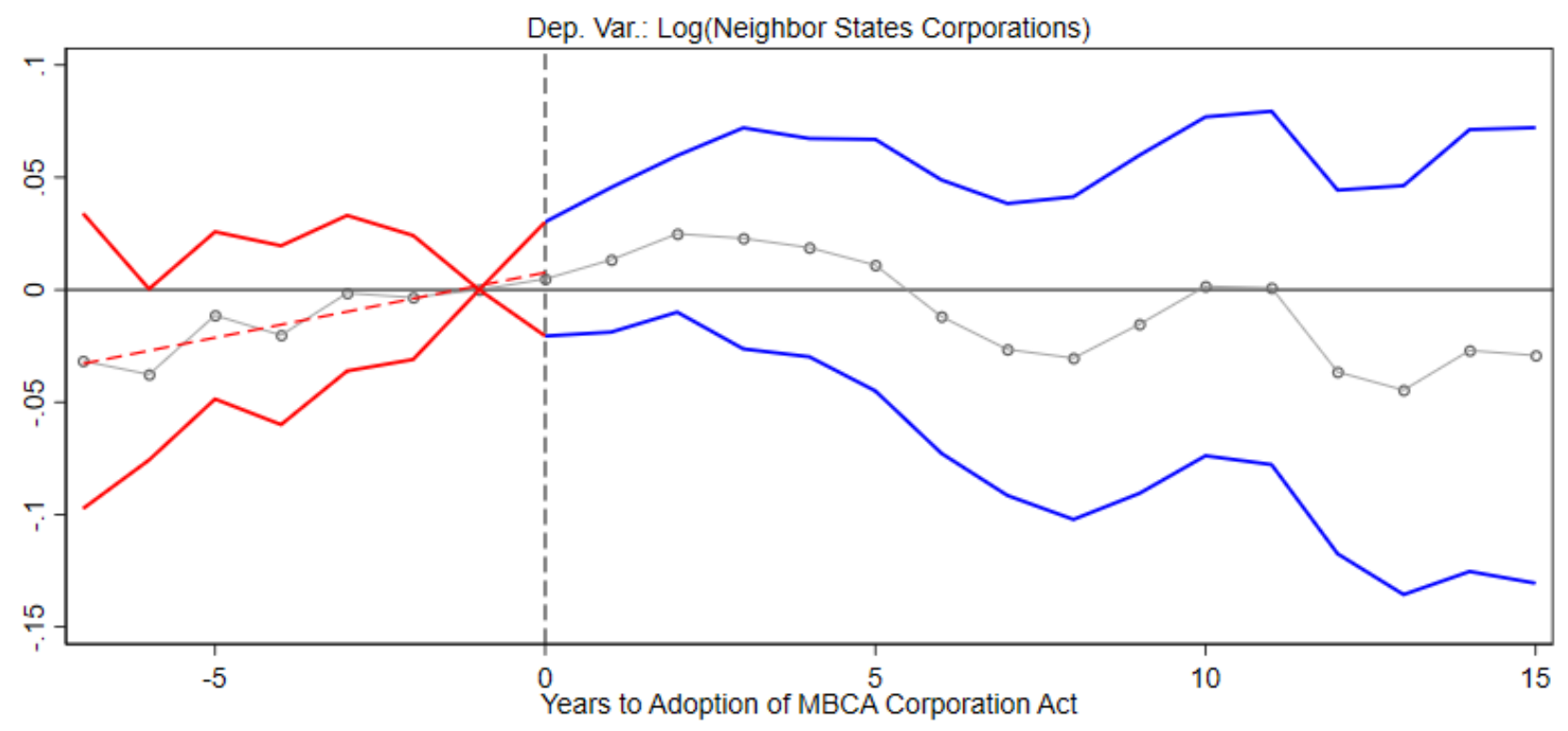

Figure A3: Main Effect: 15 Year Pre-period.

Dep. Var.: Log(Local Corporations/Foreign Delaware)

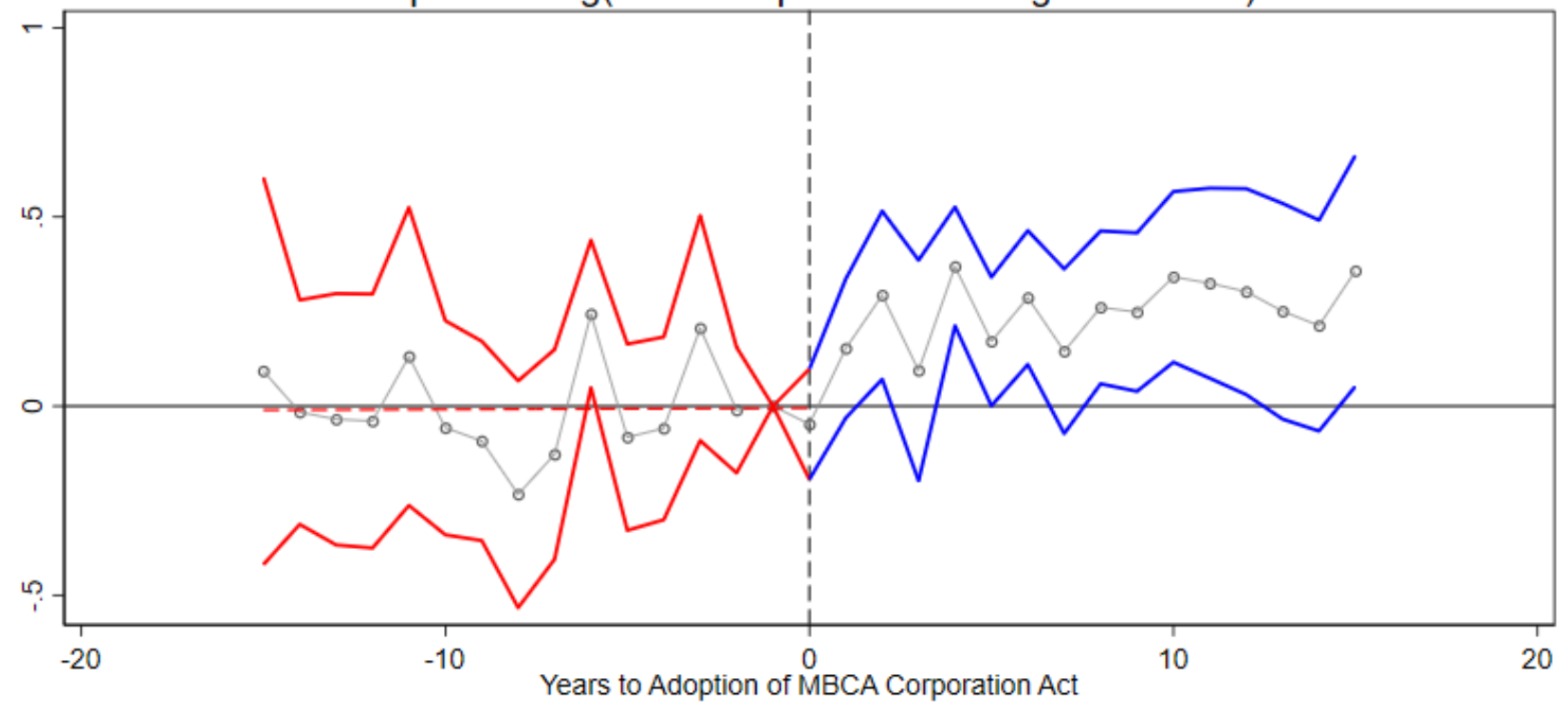


Figure A4: Robustness Test: Adding +1 to Avoid Zeroes.

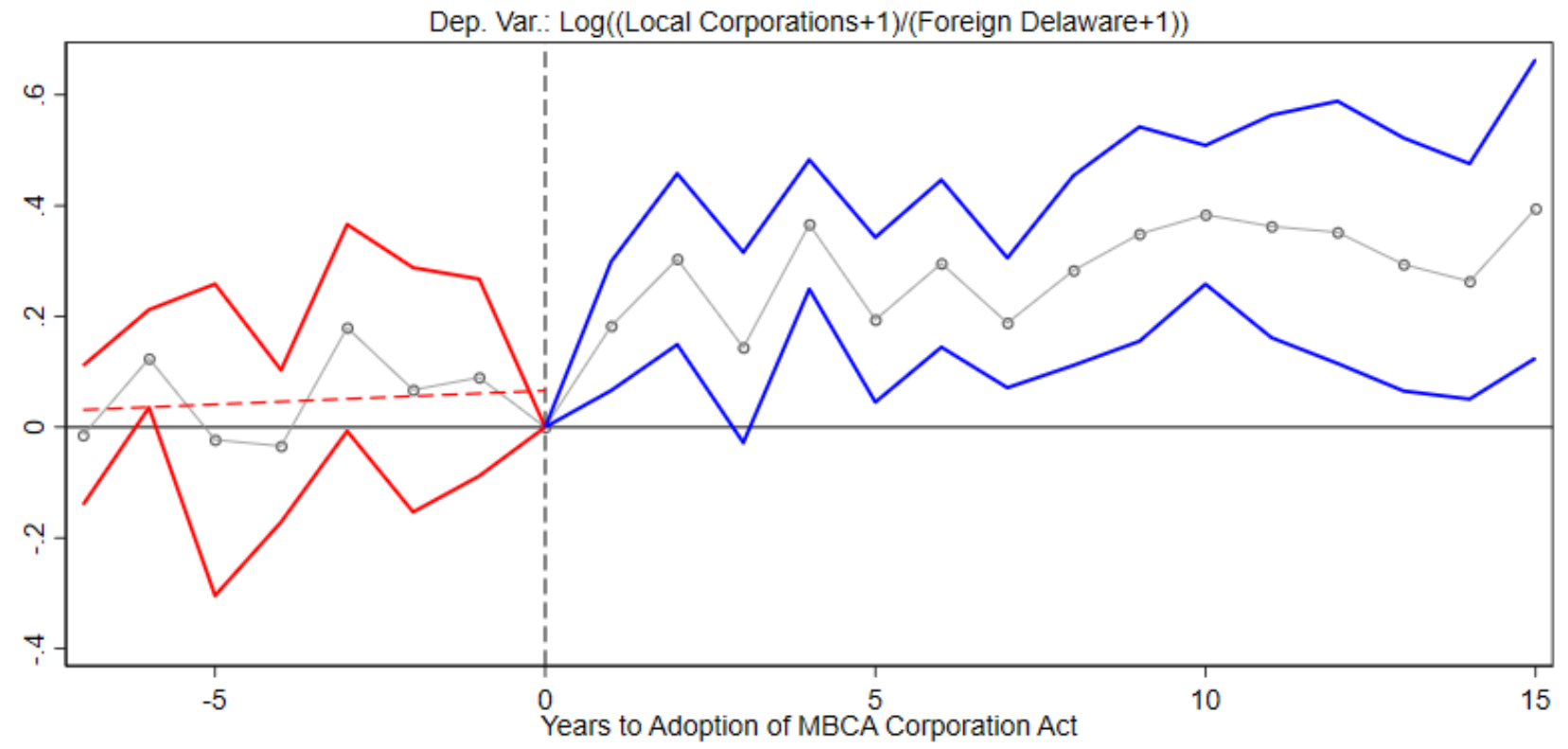

Figure A5: Robustness Test: Expanded Baseline Category.

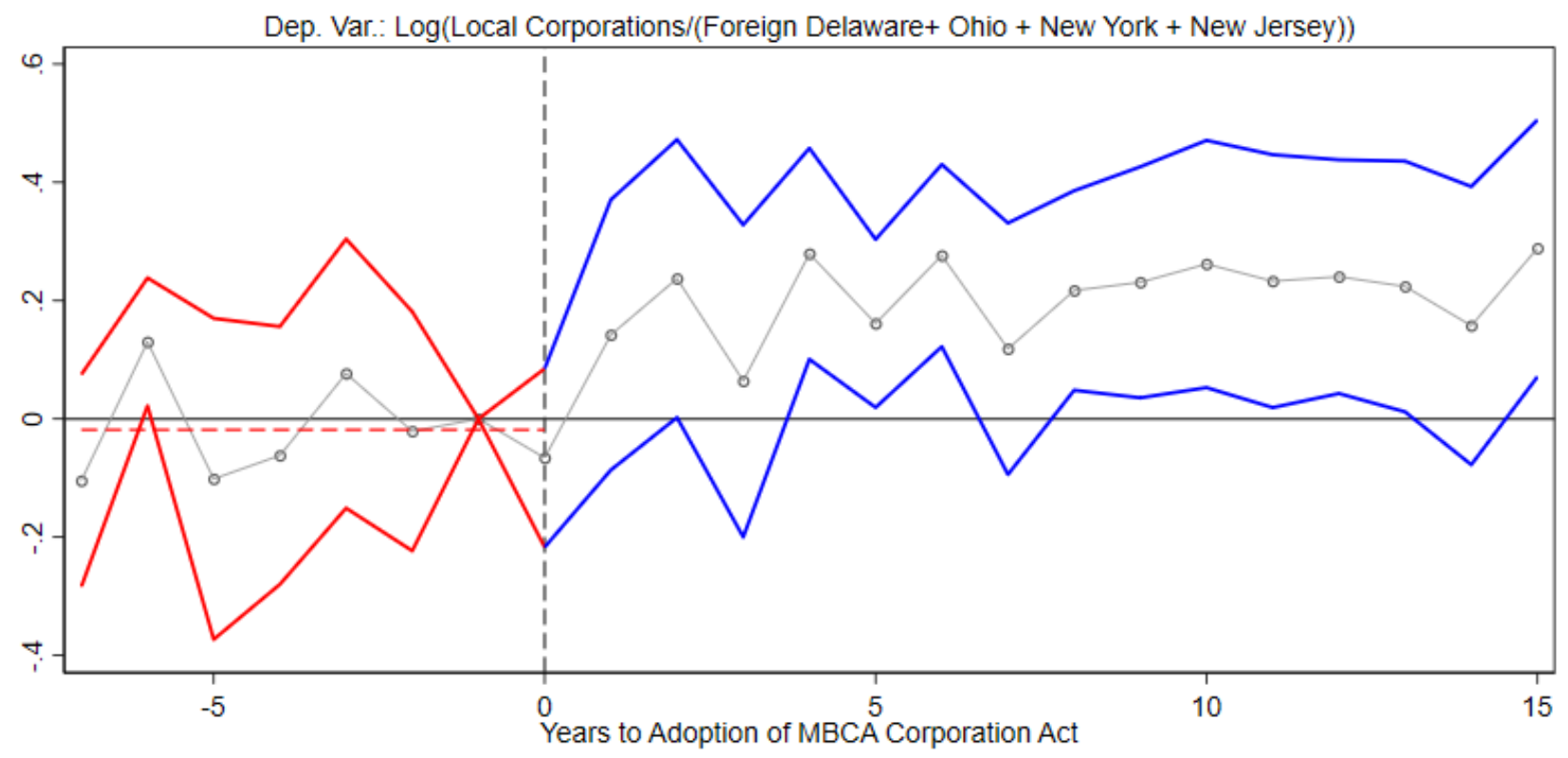


Figure A6: Difference in Differences estimates under de Chaisemartin and D'Haultfœuille (2020).

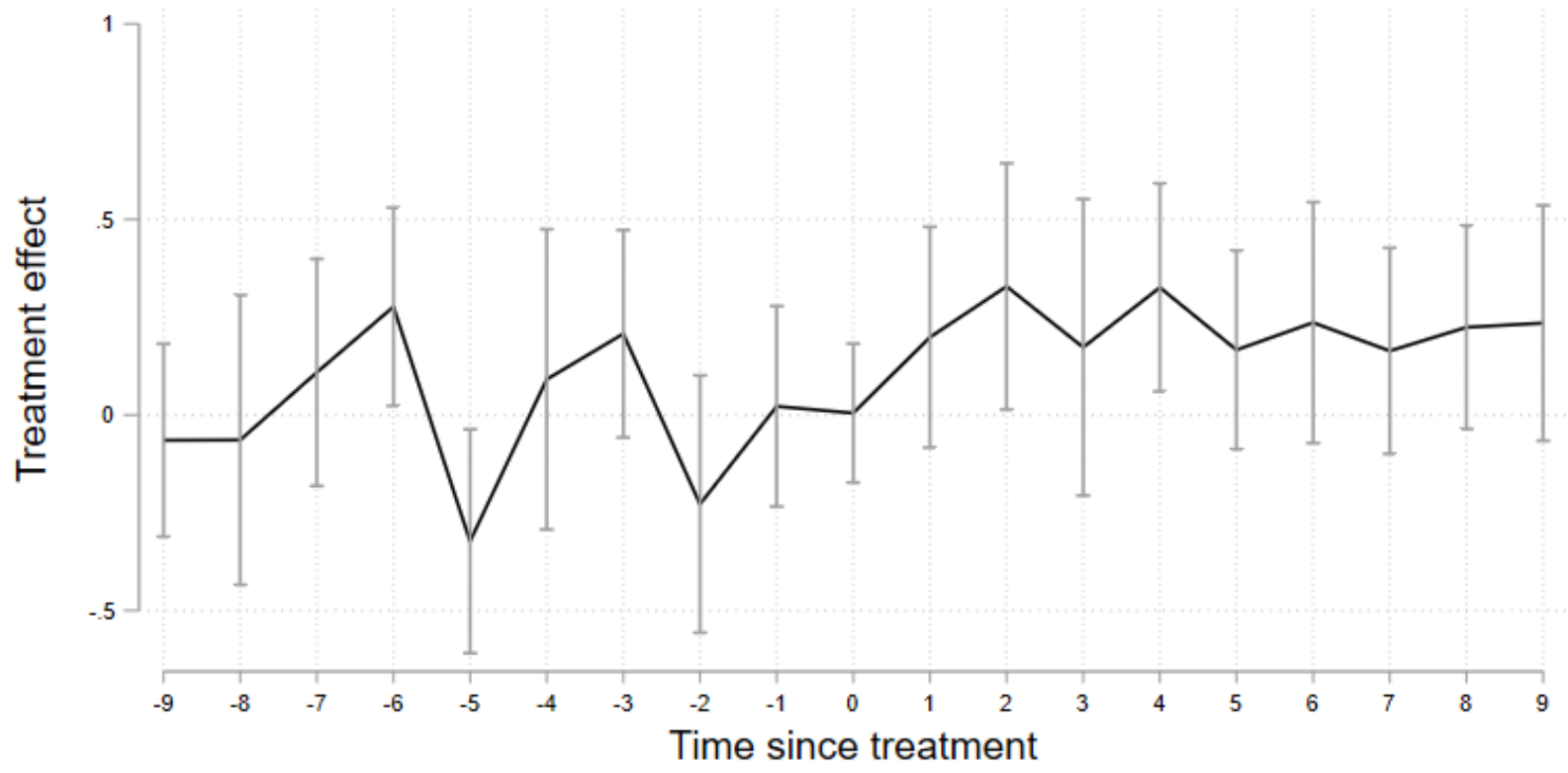


Figure A7: Heterogeneity: Individual Estimates by State.

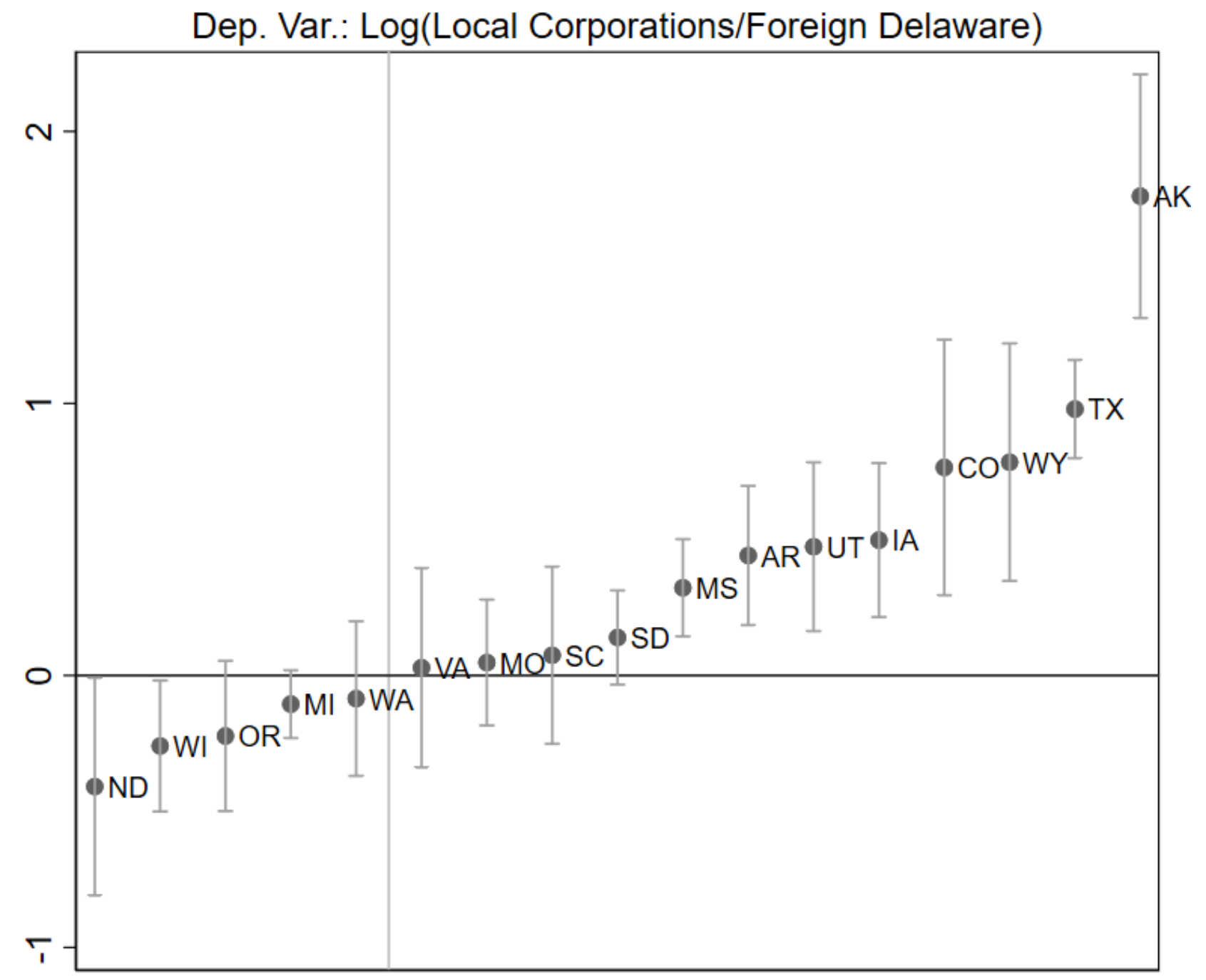

This figure reports the individual coefficients from a regression that estimates the same model as in Section 4 , but includes a different indicator for each state that introduces the MBCA. The baseline category are those states that do not introduce an MBCA. Standard errors are bootstrapped with 100 iterations. 
Figure A8: Deregulation and the Introduction of the MBCA Act

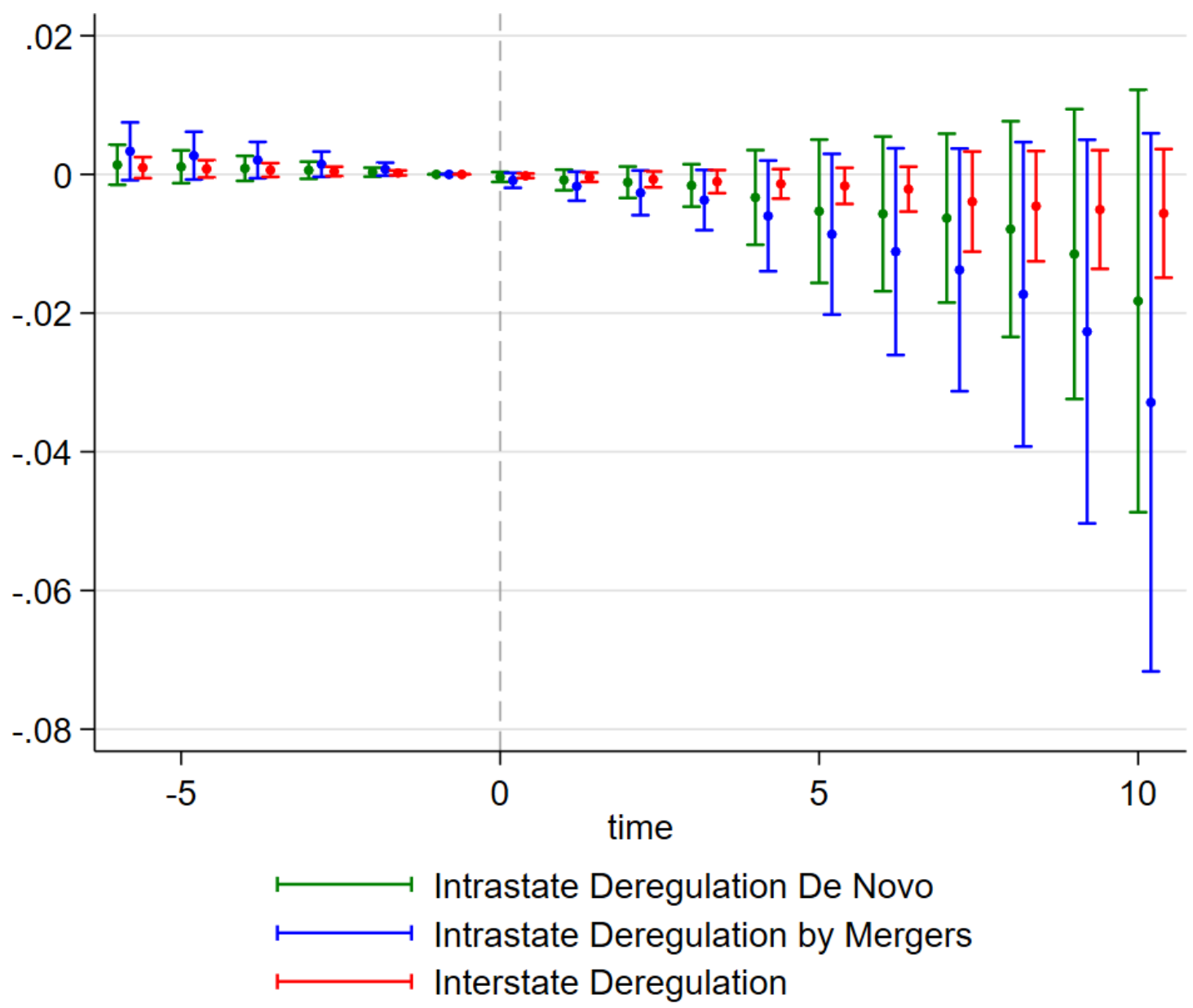

Notes: This figure 
Figure A9: State Politics and the Introduction of the MBCA Act
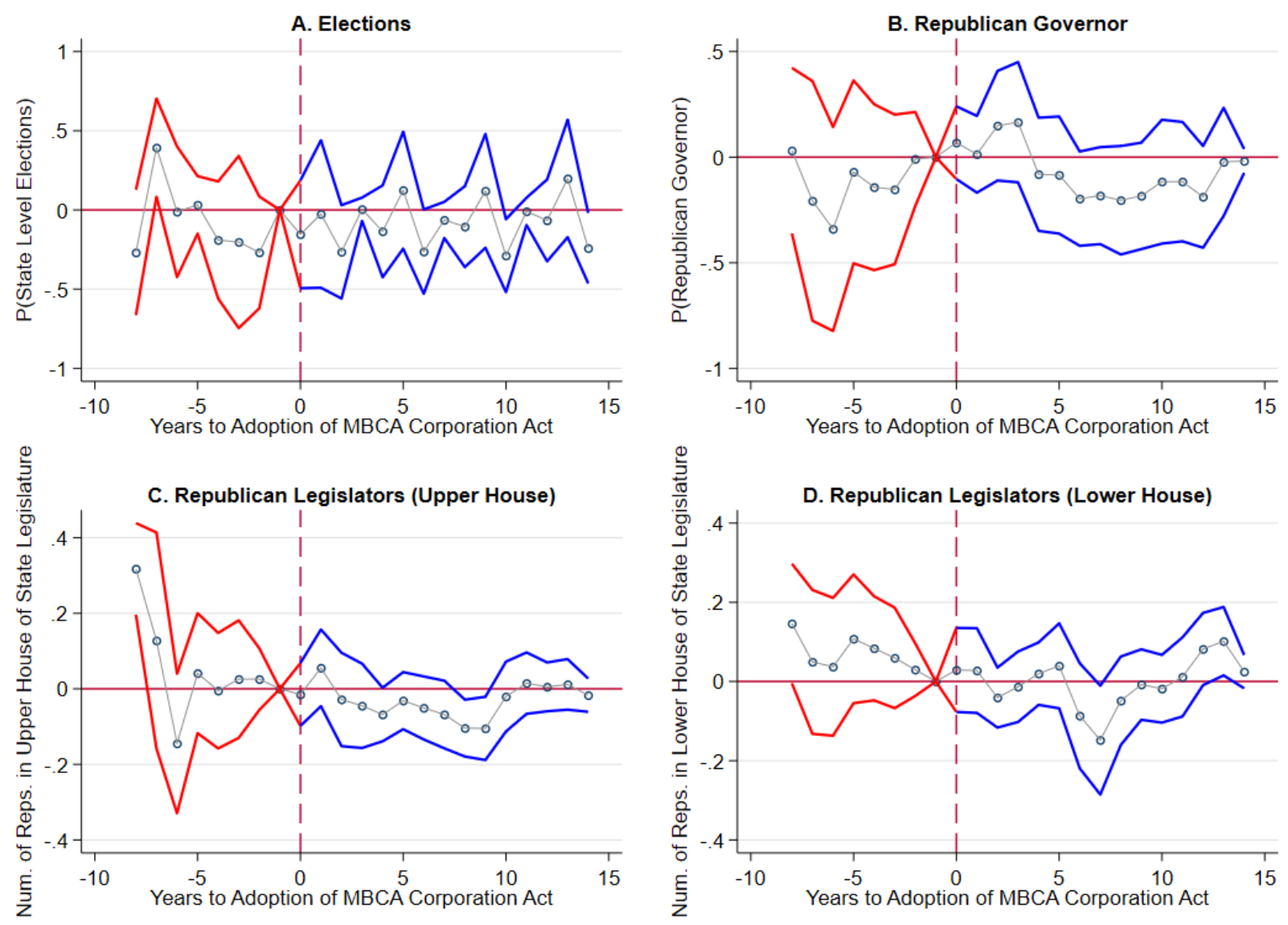

Notes: This figure 
Figure A10: Heterogeneity of MBCA Benefits by Sector (Predicted Marginal Effects)
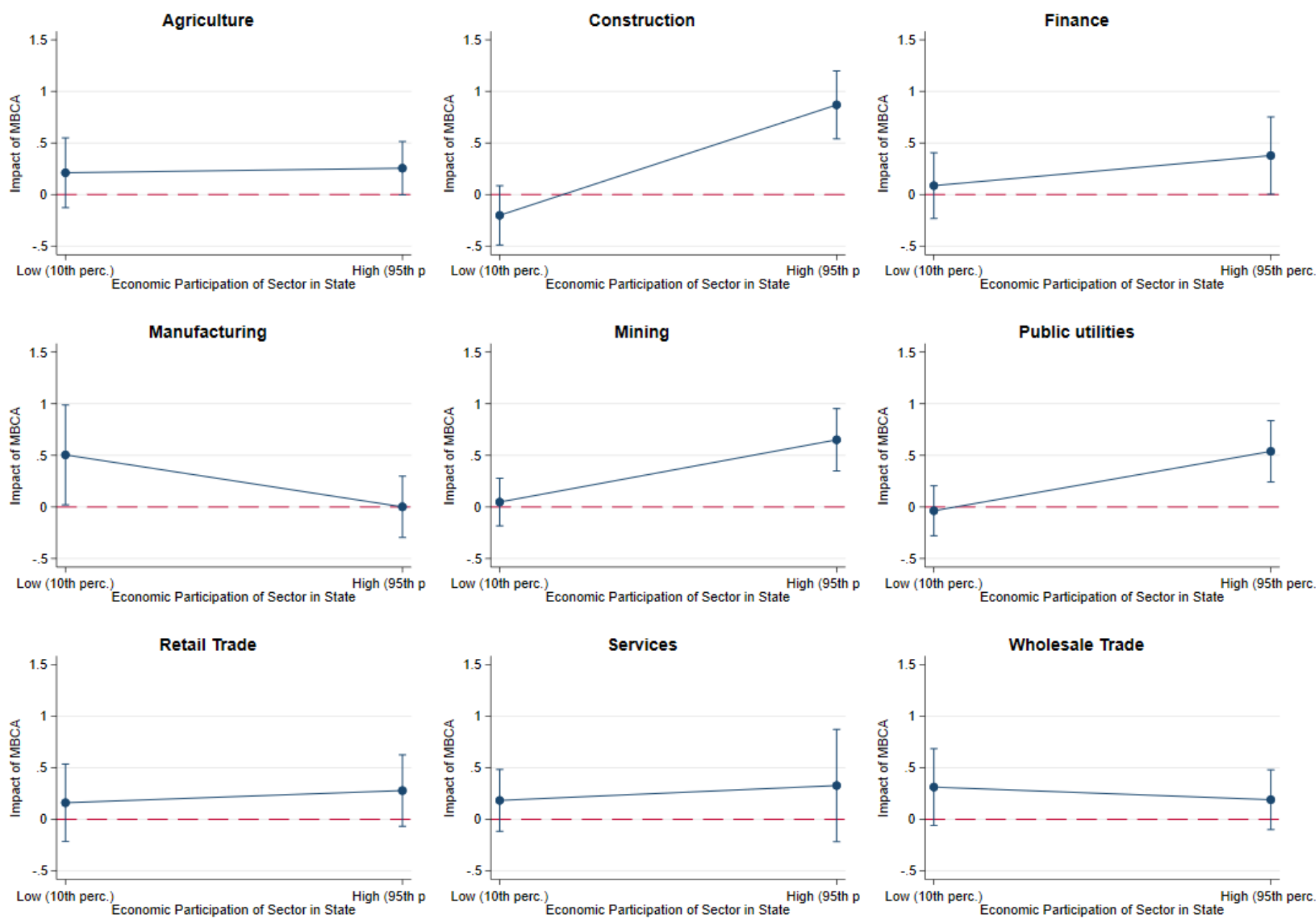

Notes: This figure reports the marginal effect of a regression that includes the estimated share of employment in each SIC sector in the 1956 County Business Patterns file for a state with a low level of presence in this sector (10th percentile), and a state with a high level of presence (90th percentile). 
Table 1: Summary Statistics CPS Data

\begin{tabular}{|c|c|c|c|c|c|}
\hline Variable & Obs & Mean & Std. dev. & Min & Max \\
\hline MBCA Adopted & 192,483 & .81 & .385 & 0 & 1 \\
\hline \multicolumn{6}{|l|}{ Labor Force Participation } \\
\hline Self Employed & 192,483 & .06 & .239 & 0 & 1 \\
\hline Wage Worker & 192,483 & .38 & .484 & 0 & 1 \\
\hline Not in Labor Force & 192,483 & .446 & .497 & 0 & 1 \\
\hline \multicolumn{6}{|l|}{ Sex } \\
\hline Male & 192,483 & .48 & .500 & 0 & 1 \\
\hline Female & 192,483 & .52 & .500 & 0 & 1 \\
\hline \multicolumn{6}{|l|}{ Race } \\
\hline White & 192,483 & .91 & .287 & 0 & 1 \\
\hline Black & 192,483 & .08 & .264 & 0 & 1 \\
\hline Other & 192,483 & .02 & .123 & 0 & 1 \\
\hline \multicolumn{6}{|l|}{ Metro (Urban vs Rural) } \\
\hline Not identified & 192,483 & .13 & .332 & 0 & 1 \\
\hline Not in metro area & 192,483 & .34 & .474 & 0 & 1 \\
\hline Central city & 192,483 & .21 & .409 & 0 & 1 \\
\hline Outside central city & 192,483 & .30 & .460 & 0 & 1 \\
\hline Central city status unknown & 192,483 & .02 & .130 & 0 & 1 \\
\hline \multicolumn{6}{|l|}{ Recent Migration Status } \\
\hline Moved Into State Last Year $=0$ & 192,483 & .985 & .121 & 0 & 1 \\
\hline Moved Into State Last Year $=1$ & 192,483 & .015 & .121 & 0 & 1 \\
\hline
\end{tabular}




\section{A Statements on the Impact of the Model Business Corporation Act on corporate law}

This appendix section provides a brief look at the role of the MBCA in simplifying corporate law and enabling business formation. The MBCA is a model (prototype) act that was implemented in different state jurisdictions to improve business conditions. Two authors of leading corporate law updates adopting the MBCA wrote contemporaneous law review articles intended to explain the differences between the existing corporation law in their jurisdiction and the updated one. George Gibson, who led the update of the Virginia corporate law, and Ernest Folk III, who led the update of the South Carolina corporate law.

This section presents quotes from these articles to provide color into the self-described experience of states updating their laws. The overall conclusion from these quotes is that there is no specific area of business that is targetted by the adoption of the MBCA. Rather, it is the improvement of the legal functioning as a whole. Further, since most of the articles are about the overall experience with the MBCA, rather than an indictment of the prior law, only a few areas of improvement are explained. The total changes in law is much wider.

\section{A.1 Folk on South Carolina}

Citation: Folk, Ernest L. 1963, "The Model Act and the South Carolina Corporation Law Revision". The Business Lawyer 18 (2):351-399.

General impression of the state of the South Carolina law before the $M B C A$.

The prior law was no more than a collection of ad hoc provisions, enacted by the General Assembly as the need arose from time to time over a period of 150 years, and given the semblance of a corporate law only by their arrangement in the usual corporate law sequence. As a consequence, the prior law suffered from a remarkable combination of gaps, ambiguities, uncertainties, redundancies, and archaic restrictions with little or no bearing on contemporary problems. (p. 351)

Updates to the process of firm incorporation.

The incorporation process was enmeshed with statutory mandates regulating the raising of capital by subscription before filing the incorporation papers, by requirements of advance newspaper notices of incorporation and finally, by ambiguous provisions for filing with both the Secretary of State and the county clerk.2 Recognizing as ground- less the fears which once prompted formalistic restrictions on the in- corporation process, the South Carolina statute, like the Model Act, seeks to simplify as far as possible the incorporation process, and to eliminate needless technicalities.

Changes to capital requirements and their timing in incorporating a firm 
Practical considerations also dictated adopting a small capital requirement as against the more logical step of dropping the capital requirement. The old law had an unweildy and complex requirement that the corporation, even before applying for incorporation, have subscriptions for at least fifty percent of its authorized shares and have paid in to the corporation at least twenty percent of the amount subscribed. (p. 355-356)

On the location of shareholder meetings

South Carolina adopts the flexible Model Act provisions which are designed to facilitate shareholder meetings and eliminate useless formalities. Like Model Act Section 22, but unlike earlier South Carolina law, shareholder meetings may be held either within or outside the state. (p. 374)

Improvements to the process and requirements to shareholder meetings

As in Model Act Section 26, a failure to hold the annual meeting not only does not "work a forfeiture or dissolution of the corporation" but also it "shall not affect otherwise valid corporate acts". The South Carolina law also makes it clear that the old practice of closing the stock books is not at all the preferred practice, by first specifying the record date procedure and then permitting the closer stock transfer books only as an alternative. Indeed, it may well be that, following the logical New York rule, South carolina will some day altogether abolish the clumsy procedure of closing the books. (p. 374)

\section{A.2 Gibson on Virginia in 1958}

(Note: This article, published in The Business lawyer, was an open letter to the state of Utah explaining the benefits of adopting the MBCA when updating corporate law and encouraging Utah to consider doing so in their upcoming process of legal updates.)

Citation: Gibson, George D. "Virginia's Experience With the Model Business Corporation Act". The Business Lawyer 13 (4): 706-717

On choosing to update Virginia's corporate law

The first question Virginia had to face was whether to patch her existing law by piecemeal corrections or to attempt a wholly new one. Conceivably that same question may face you Utah legislature. There were two difficulties in any plan of piecemeal revision. One was that in the half century the law instead, so many amendments had been made to it from time with shifting terminology and overlapping effect, that it seemed harder to repair the automobile than to buy a new one. There does come a time after all when every automobile must be in. In the second place, every provision of the old law had put in by somebody and changing it would arouse his opposition, if still around. (p. 706)

On the merits of the MBCA compared to other jurisdictions and their corporate law. 
Once we accept the premise that a wholly new law is to be enacted, the first instinct of the prudent lawyer is to look for a precedent, form book with scissors, as the clients say. Surely no one would dream of writing a corporate mortgage all on his own some Sunday afternoon. And so it is with a corporation law. Singularly enough, the great corporation states do not afford a good precedent today. By every test the three greatest states are Delaware, New York, and New Jersey. New Jersey has allowed her status to become antiquated and is certainly no guide for general housecleaning. New York is admittedly in the same fix and is presently engaged in a large-scale effort to reconsider and revise the whole of her corporation law. Even Delaware, though the most important corporation state, does not have a really simple and up-to-date corporation law. Moreover her name is associated in ordinary judgement with extremes of corporate privilege which do not ahve broadest appeal for reasonable, workable, middle-of-the-road legislation. In contrast, the Model Act of the Committee on Corporate Laws of the Section of Corporation, Banking and Business Law of the American Bar Association was designed to fill just exactly this need. it reflects the practical experiences of lawyers in various parts of the country. It is workable. It is fair. (p. 707)

On the merits of joining a standarized framework.

You will derive increasing benefit from the use of this act because of its growing acceptance. When the Virginia Code Commission first selected it as a model, it had been adopted in only 3 states. Now it has been adopted in 7 states, 1 including Colorado, your geographical next-door neighbor. It is receiving favorable consideration from the revision committees in New York and is pending before the authorities of several other states. (p. 707)

\title{
A.3 Gibson and Freeman Jr on Virginia in 1967
}

\author{
Citation: Gibson, George D. and George C Freeman Jr. "A Decade of \\ the Model Business Corporation Act in Virginia" Virginia Law Review 53
}

(6):1396-1423.

Assessing the state of corporate law before the $M B C A$

Before 1957 Virginia corporation law was a thicket of confusions. Major corporate transactions were frequently blocked by uncertainties of meaning, and reasoned opinions were in many cases all that could be obtained. These uncertainties were eliminated by the Virginia Act. Even its application to preexisting corporations, which had been feared as a possible source of many problems, proved simple and easy.15 Subsequent administration, under new forms provided by the State Corporation Commission, has been speedy and efficient. (p. 1396)

On whether directors can act without a meeting

In 1956 one of the suggestions most frequently urged on the Code Commission was that directors be allowed to act without a meeting, a course of action already permitted stockholder. 
On the process for corporate readjustments

"Before 1957 the graveyard of Virginia corporation law had been the inscrutable and impractical provision that no corporation "shall . . . have the power to change the voting rights and/or the priority as to assets or dividends of any stockholder." Accordingly, "the most important provision" of the new act was the elimination of this rule in its entirety and the substitution of a completely new system. Under the new order (a) only a two-thirds vote of all voting shares is needed instead of a nine-tenths, (b) changes of any nature whatever may be made when so approved, and (c) a class vote, even if the particular class has no right to vote under the charter, is required for changes of important rights of the class, whether accomplished by amendment, to which alone the previous restriction had been applicable, or by merger or consolidation. 